\title{
Title: Inter-thinker consistency of language activations during abstract thoughts
}

Aviva Berkovich-Ohana ${ }^{1,2, *}$, Niv Noy $^{2}$, Michal Harel ${ }^{2}$, Edna Furman-Haran ${ }^{3}$, Amos Arieli $^{2, \mathrm{a}}$ and Rafael Malach ${ }^{2, \mathrm{a},{ }^{*}}$

${ }^{1}$ Faculty of Education, The Edmond J. Safra Brain Research Center for the Study of Learning Disabilities, and The Integrated Brain and Behavior Research Center, University of Haifa, Haifa, Israel

${ }^{2}$ Department of Neurobiology, Weizmann Institute of Science, Rehovot 76100, Israel

${ }^{a}$ These authors contributed equally to this work

${ }^{3}$ The Life Sciences Core Facilities Department

* Corresponding authors

Materials \& Correspondence authors:

Rafael Malach, Department of Neurobiology, Weizmann Institute of Science, 234 Herzl St. Rehovot 7610001, Israel.

Telephone: +972-8-9342758

E-mail address: rafi.malach@gmail.com

Aviva Berkovich-Ohana, Faculty of Education, The Edmond J. Safra Brain Research Center for the Study of Learning Disabilities, and The Integrated Brain and Behavior Research Center, University of Haifa, Haifa, Israel.

Telephone: +972-503-681889

E-mail address: avivabo@edu.haifa.ac.il

Keywords: abstract-thoughts; visual imagery; default mode network; language; fMRI 


\begin{abstract}
Human brain imaging typically employs structured and controlled tasks to avoid variable and inconsistent activation patterns. Here we argue against this assumption by showing that an extremely open-ended, high level cognitive task- loosely defined as "abstract thinking" leads to a precise, and highly consistent activation maps. Thus we show that activation maps generated during such cognitive process were precisely located relative to borders of well-known networks such as internal speech, visual and motor imagery. The activation patterns allowed decoding the thought condition at $>95 \%$. Surprisingly, the activated networks remained the same regardless of changes in thought content. Finally, we found a remarkably consistent activation map across individuals engaged in abstract thinking. The activation to abstract thinking bordered, but strictly avoided visual and motor networks. On the other hand, it partly overlapped with left lateralized language networks. These observations were supported by a quantitative neuronal distance metric analysis. Our results reveal that despite its high level, and varied content nature- abstract thinking activates surprisingly precise and consistent networks in the participants' brains.
\end{abstract}


'Thinker' refers to: The agent of thought; Intellectual, one who tries to use his or her intellect to work, study, reflect, speculate on, or ask and answer questions with regard to a variety of different ideas" (Wikipedia).

\section{Introduction}

A prominent experience common to all humans is that thoughts never cease. Experience sampling studies report on $46 \%$ of the individual's awake time spent in thinking ${ }^{1,2}$, making it a significant proportion of our cognitive experience. There have been ample attempts to classify thought types, and to suggest their underlying neural mechanisms. One form of thought is abstract reasoning, the capacity to reach novel conclusions on the basis of existing premises - not directly grounded in sensory experience. This process necessarily depends on multiple underlying capacities, but the extent of this reliance on specific mechanisms is a subject of considerable debate ${ }^{3}$. Given that reasoning and abstraction is of utmost importance to human's intellectual ability, development and behavior ${ }^{4}$, a critical question is to understand: What are abstract-thoughts (AT) "made of"?

In using abstract thoughts we aimed to explore the type of reasoning that can be loosely defined as "thinking that encompasses all operations by which cognitive agents link mental content in order to gain new insights or perspectives" 5 . However, for simplicity of expression, we will exclude the term "reasoning" form the rest of the text and will instead use the word "thinking".

So far, there were a surprisingly few studies attempting to examine this question. A major hindrance, it appears, is the prevailing assumption that the highly uncontrolled and open-ended nature of such high level tasks will be bound to lead to variable and inconsistent activation patterns. However, as was previously shown ${ }^{6}$, such an assumption may not be always justified, particularly when the task constitutes natural and prevailing dimensions of human cognition. Here we aimed to examine to what extent the high level nature of abstract thinking, the inevitable changes in content involved and the different individual styles engaged, will lead to highly variable activation patterns.

However, it is important to first clarify what concepts have been proposed regarding to the possible contents of abstract thinking. Several major candidates appear when reviewing the literature: the neural mechanisms supporting language, visual and motor imagery (embodiment), or mentalization. We thereby briefly introduce the theoretical and empirical evidence which supports each one of these views.

The view that language determines thought

The relationship between thought and speech is one of the oldest yet still debated problems in psychology, logic and linguistics ${ }^{7,8}$. Indeed, various linguistics claim that thoughts and speech are strongly inter-related ${ }^{9-11}$, and that the representations afforded by language are likely to be central to thinking ${ }^{12-14}$, to the point that language shapes thought and world-view ${ }^{11}$, albeit other linguistics argue against this view ${ }^{\text {e.g. } 15}$. Early 
studies attempting to examine this question through behavior and introspection have revealed mixed results ${ }^{8}$. Yet, some neural evidence supports the connection, by showing for example that abstract concepts elicit greater activity in the inferior frontal gyrus and middle temporal gyrus compared to concrete concepts, suggesting greater engagement of the verbal system ${ }^{\text {meta-analysis by } 15}$. In addition, volume reductions in brain areas involved in language have been found to be associated with formal thought disorder in schizophrenia 17. Other studies have attempted to map the brain activations associated with inner speech, a potential component of AT, showing different results obtained by different research groups reviewed by 18 .

Visual imagery and its connection to abstract-thought

Another possibility is that thinking and abstraction proceed via the use of quasiperceptual or embodied mental models, in which case the high-level spatial and perceptual representations upon which the models are built would be critical for thinking ${ }^{19,20}$. This is because our thoughts rely on constructions we build from and meaning we assign to what we sense or recall. A different but related line of research (based on intracranial recordings of neuronal activity conducted in patients) suggests that abstract representations of persons and objects, which are being represented by 'concept cells' in the medial temporal lobe, may play a role in building conceptual associations ${ }^{21}$. A metaanalysis ${ }^{16}$ showed that concrete concepts (e.g., focusing on the means required to achieve a specific goal - the 'How') elicit greater activity in the posterior cingulate, precuneus, fusiform gyrus, and parahippocampal gyrus compared to abstract concepts (e.g. focusing on the purpose of an action - the 'Why'), suggesting greater engagement of the perceptual system for processing of concrete concepts, likely via mental imagery. Interestingly, a more recent attempt to differentiate the neural activity associated with abstraction and concretization revealed that concretization was associated with activation in frontoparietal regions implicated in goal-directed action, in support of the embodied cognition view, while abstraction was associated with activity within posterior regions implicated in visual perception ${ }^{22}$.

The 'mentalizing network' - the default mode network (DMN)

Several studies ${ }^{23,24}$ have shown that abstraction mindset (thinking 'Why') activates the 'mentalizing network' - a widespread network of regions associated with theory-of-mind, including the temporal pole, the medial prefrontal cortex, the precuneus and the right temporo-parietal junction. This network largely overlaps the default mode network $(\mathrm{DMN})$, active when we engage in internally oriented rather than externally oriented tasks ${ }^{25,26}$. In support of that view, it was shown for example that thoughts arising while viewing artworks are related with DMN activity ${ }^{27}$.

A potentially informative strategy to assess which of these functions actually dominate abstract thinking can be employed by taking advantage of the recently obtained detailed mapping of the functional specializations in the human cortex. Such knowledge 
has been accumulated at an unprecedented rate, mainly based on functional brain imaging using functional magnetic resonance (fMRI). Thus, detailed "atlases" that define the functional selectivity of literally every voxel in the human cortex are now available through thousands of mapping studies ${ }^{28,29}$. Against this backdrop of detailed known functional atlases, it thus may become feasible to deduce the cognitive components involved in abstract thinking simply by relating the brain activations when participants engage in such abstract thinking processes to the known network selectivity of the cortex, including language, visual imagery, sensory-motor tasks and intrinsically oriented functions. Here we report on the results of an experiment in which such comparison was achieved directly within individual participants.

A second issue of great interest addressed using this direct comparison is whether different contents of thought produce differential activations. Finally, we ask whether individuals that engage in abstract thinking activate similar brain networks, in an analogous fashion to, e.g. sensory activations when confronted with identical stimuli ${ }^{5}$.

\section{Results}

Our analysis included twenty out of twenty-three healthy participants (see methods) that underwent three fMRI scans (figure 1A): in the first and second scans the abstract thoughts condition (AT) was compared to both visual imagery and language tasks, while the third scan was a Visual Categories scan used to define visual and DMN regions. Subsequently, the participants were interviewed about their experience.

\section{First-person reports}

The personal reports of the mental content during the different conditions are provided in Table 1. As can be seen, mental contents during the two abstract thought conditions were different for all participants, irrespective of the order of the scans (given in column 2).

To examine the possibility that individual participants relied on different cognitive strategies, and thus belong to different phenomenal types with which might show different neural patters, we used the personal reports to create phenomenal groups. As the free descriptions showed variable content (see Table 1), we used the personal scaling of the verbal and visual content. While the verbal content was always high (graded as 4 or 5 on a 1-5 Likert scale, accept for one participant who graded 3), we used the visual grading, which was more heterogeneous. Participants were divided into to two categories, low visual content $(n=12)$ and high visual content $(n=3)$, chosen as those who graded the visual content as 1 or 2 , vs, those who graded 4 or 5 , respectively.

\section{Performance measures}

Performance on the Letters WM showed a high $(97 \% \pm 7.3)$ success rate across tested participants. For the two abstract thinking conditions there was no significant selfreported difference between thought 1 and 2 (on a 5-point rating scale): participants rated 
the level of internal speech as $4.59 \pm 0.59$ and $4.64 \pm 0.58$, respectively; the level of internal visualization as $1.82 \pm 1.30$ and $2.87 \pm 1.45$, respectively; and the level of interest as $3.60 \pm 1.40$ and $3.44 \pm 0.88$, respectively.

\section{fMRI activations}

Turning now to the brain activations as mapped with fMRI (the peak Talairach coordinates of the significant clusters in all the contrasts are reported in supplementary Tables S1-S8), figure 2 shows the average group activation across the 21 participants during abstract thinking about 'free will' (AT1- figure 2A) and 'man's nature' (AT2 figure $2 \mathrm{~B}$ ). As can be seen, both tasks resulted in a robust left lateralized frontal activation, including the supplementary motor area (SMA) and the premotor dorsal (PMD), both in the medial and middle frontal gyrus; Inferior frontal gyrus (IFG) including Broca area (Brodmann area BA-45 and BA-47), as well as middle temporal gyrus (MTG) including (BA-21 bordering Wernicke area), all regions known to play a part in language processing ${ }^{30}$; AT also activated the temporal pole (TP). Interestingly, despite the different content and subject matter of the thoughts, the activated networks were remarkably similar (see green contours from AT1 map superimposed onto AT2 figure 2). Moreover, the inter-participant variability was low for the same content (figure 3 ), indicating that AT produced a robust, highly consistent and specific pattern of activation across different individuals.

To relate the activations during the AT to known cortical functionality at the individual level, each participant underwent a battery of tasks (figure 4) including a Visual Categories scan used to map visual regions and define the deactivated DMN (figure 4B). Conditions of language tasks (figure 4C-E) - were employed to define language-related activations $(4 \mathrm{D}, 3 \mathrm{E})$ as well as working memory activation (4C). Two sensory-motor visual imagery tasks (figure $4 \mathrm{~F}-\mathrm{G}$ ) were conducted to allow examination of potential visual imagery components during abstract thinking.

In the Visual Categories scan (figure 4B), contrasting all four visual stimuli vs. rest revealed the expected visual-induced increase in BOLD signal in high order visual ROIs, including for example bilateral posterior fusiform ( $\mathrm{pFs}$ ) and lateral occipital (LO) cortices e.g. 31 . Additionally, it revealed the expected and corresponding task-induced reduction (relative to the fixation baseline) in BOLD signal in the DMN nodes, including the bilateral Precuneus (Prc) and inferior parietal lobule (IPL), as well as superior frontal gyrus (SFG), as previously shown ${ }^{\text {e.g. } 32}$.

Subsequently, the BOLD activations in the working memory and two language tasks were examined (figure 4C-E). The Verbal Fluency and Sentence Conjugation tasks showed a typical left-lateralized activation in language regions (figure 4D-E), including inferior frontal gyrus (IFG), Broca area (Brodmann area BA-45 and BA-47), and Wernicke area (BA-21), all regions known to play a part in language processing ${ }^{30}$. The Working Memory task (figure 4C) showed a bilateral activation generally resembling the 
other two language task activations. However, as expected, there was a stronger activation at the inferior parietal cortex (IPC, both dorsal and ventral), suggested as the site of the phonological loop ${ }^{33}$.

The visual imagery tasks (figure 4F-G) showed premotor (PMD) areas, compatible with previous reports ${ }^{34,35}$; parahippocampus, possibly reflecting the representation adapted to navigation-related motor tasks ${ }^{36}$; precuneus (Prc), a key part of the neural substrate of visual imagery occurring in episodic memory retrieval ${ }^{37}$; and the inferior parietal lobule (IPL), a region related to imitation imagery ${ }^{38}$ and sense of agency ${ }^{39}$. The results are in agreement with a previous meta-analysis ${ }^{15}$ which showed that concrete concepts (focusing on the 'How') elicit greater activity in the posterior cingulate, precuneus, fusiform gyrus, and parahippocampal gyrus compared to abstract concepts (focusing on the 'Why'). Imagery of Tools showed a left-lateralized pattern compared to Navigation imagery, due to the activation of the contra-lateral hemisphere in the righthanded participants during the imagery of manipulating tools, while imagery of whole body movement involved a bilateral activation ${ }^{35}$. Also, Tools imagery showed a stronger deactivation over DMN regions compared to Navigation imagery.

We then examined to what extent the AT network overlapped any of the cortical activations associated with other tasks (figure 5). This comparison was done by superimposing the activation of AT1 (5A, marked by a green contour) onto all other taskrelated activations. Comparing BOLD signal in the AT network with high order visual activations (figure 5B), revealed a complete segregation.

Comparing the BOLD activations of the AT network to that produced by the working memory and linguistic tasks (figure 5C-E), revealed a substantial overlap particularly in more posterior regions (e.g. pre-SMA). However, the AT task activated regions that were not significantly activated during the linguistic tasks. When comparing the AT network to activations generated when the participants engaged in imagery of tools (4F) and navigation (4G) it can be seen that although imagery and AT produced activations in close proximity - there was a complete segregation of the activations for these different tasks.

To study the question of the DMN involvement during AT, we superimposed the deactivation of the DMN during the Visual Categories scan (figure 6A, marked by a red contour) onto the AT and language activations. As can be seen (figure 6B), the DMN was not activated during the AT condition, while deactivated during the working memory and language tasks $(6 \mathrm{C}, 6 \mathrm{E}, 6 \mathrm{~F})$. An ROI analysis on the mean beta values of four DMN regions (Prc and IPL, Bilaterally) reveled that indeed the DMN regions during both AT1 and AT2 were significantly less deactivated compared to the working memory and language tasks (figure 7).

An important concern could be that AT were prevalent also during the rest condition. In order to examine this possibility, we compared the AT condition to the rest condition 
by contrasting both conditions to a third (language) condition. The results are depicted in supplementary figure S1. As can be seen the AT1 and AT2 conditions produced drastically different activation maps when compared to the rest condition. These differences were mainly and consistently evident in frontal regions (see arrows).

\section{Neural pattern classifier}

If indeed the activation patterns of the thought conditions were highly reproducible across individuals, this may allow to successfully predict the cognitive state of the individual participants directly from their activity patterns. To examine this possibility, we performed a multi-variate, leave-one out, classifier approach (see methods for details) in which the pattern of activation of individual participants was compared to the average patterns across the rest of the group for five bulk conditions. When including all cortical voxels, our ability to predict the thought condition (averaged across both thought tasks) compared to the other bulk condition categories (language, imagery, working memory and visual) using this analysis resulted in a remarkable $95 \%$ performance (19 out of 20 individuals, chance performance $20 \%$ ). When including only $50 \%$ of the voxels showing low variability the performance increased to $100 \%$. The decoding efficiency of the AT condition, compared to all bulk conditions was highly significant $(\mathrm{p}<0.05$, permutation test, see methods for details).

\section{Neuronal distance results}

The multi-variate approach allowed us also to compare the similarity (neuronal distance - see methods) in activation patterns across the different conditions. The results are depicted in figure 8A-C and supplementary figure S2. Statistical analysis of the bulk conditions revealed that the language tasks were significantly more similar to the AT conditions compared to the other tasks (figure 8C).

To examine the possibility that different phenomenal categories might show different neural patterns during the AT conditions, we contrasted the AT phenomenal groups described above. Correlation coefficient between AT1, AT2 and bulk AT was performed with other conditions in each participant. Student's t-test was performed between the correlation coefficients comparing the two phenomenal categories. No significant difference was found for either AT1 or AT2 (supplementary figures S3A and S3B, respectively). Additionally, average correlation coefficients of AT1 and AT2 with other conditions in the two categories as well as bulk AT with other conditions in the two categories are displayed (supplementary figure S3C).

Similar to our findings in the whole group of participants, AT1 and AT2 had the highest correlations with significant differences found in almost all comparisons to other conditions performed separately in the high and low visual content groups. Exceptions were correlations in the high visual content group, with no differences between correlations of AT1-AT2 compared to AT1-sentences, AT2-letters, AT2-imagine navigation, and in the bulk with AT2-working memory.

\section{Inter-participant variability}


To obtain a quantitative assessment of the inter-participant variability we calculated the distance of each participants' patterns from the mean for each conditions. The results (average \pm SEM) are displayed in bars histogram (figure 9). As can be seen the AT conditions showed a similar levels of inter-participant similarity to all other conditions.

\section{Discussion}

The first issue that our results address is how sensitive was the AT activation to thought content. Our study reveals that the pattern of activation was invariant to the specific content of the AT as illustrated by the remarkably precise overlap between the activations produced by the two types of AT (figure 2). This suggests that different AT contents engage similar networks when viewed at the resolution of BOLD fMRI. The highly reproducible nature of the activation patterns during the AT conditions across individual participants allowed us to successfully predict the engagement of participants in thinking as compared to the other tasks based on their activation patterns alone. This was highly successful when averaging the groups of conditions together $(95 \%$ predictability for all voxels, $100 \%$ predictability for the $50 \%$ least variable voxels). Thus, the ability to predict the AT condition from the patterns of activity compared to all other conditions was highly significant, again illustrating the consistent nature of the AT activation pattern across individual participants. It is important to note that the similarity that we observed between the two AT tasks was not only evident qualitatively at the level of univariate responses, but was also significantly higher in our multi-variate pattern similarity analysis (see figures 8 and S1). Furthermore, this similarity was revealed under two independent scans, which may have introduced some mismatches unrelated to the neuronal activations.

An important question concerns the source of the similar activation patterns across the two AT conditions. One possibility could be that the similar activations were generated by a large overlap in the specific contents of thoughts despite the different questions posed for the two AT conditions. The other possibility could be that the activation patterns, at least at the fMRI resolution, could not differentiate between the subtle changes in content- and reflected more general aspects- such as cognitive strategies, recursive thinking ${ }^{40}$. The similar activations to different AT contents supports the latter conclusion. This conclusion was strengthened by the participants' reports indicating that their mental content during the two abstract thought conditions were different in all cases (Table 1).

The second issue that our results address is how sensitive were the AT activations to individual differences. We found that despite their high cognitive level and rather abstract and vaguely defined nature, AT produced a surprisingly consistent and specific pattern of activation across different individuals (figure 3). It could be argued that averaging the patterns of activations across a large number of participants may have masked distinct thought contents and strategies in individual groups. To examine this possibility, we 
searched in the post-hoc subjective reports for indications of distinct sub-grouping of mental content during the AT. We indeed identified one such distinction related to the level of visual imagery during one or both AT conditions. A separate analysis of these two subgroups revealed no significant group differences (supplementary figure S3). This remarkable consistency across subjects was further supported by a quantitative estimate of the inter-participant variability in activation patterns (figure 9) which revealed largely similar levels across the different conditions including the visual stimulation ones. This finding suggests that across individuals the overall cognitive strategies employed during abstract thinking were largely similar, despite the inherent open nature of AT. This surprising similarity is compatible with previous observation in other systems, indicating that participants show a remarkable level of "synchronization" in their cortical activations when confronted with naturalistic stimuli ${ }^{29}$.

The third issue we address is - what is AT "made of"? - i.e. with which known taskrelated networks AT activations overlap most prominently? Our approach directly tested several major candidates: visual imagery, mentalization, and the neural mechanisms supporting language. We also compared the AT activations to known task and sensory networks - most importantly somatosensory and motor representations.

When examining the relationship of activations during AT to various working memory and language production tasks, we found a substantial overlap (see figure 5C-E) in language areas (e.g. Broca, Wenicke). This overlap is in line with theories proposing a close association between language and thought. A particularly interesting theoretical link of this kind has been recently proposed by Berwick and colleagues ${ }^{41}$, suggesting that the emergence of inner thoughts actually set the evolutionary stage for language development.

Additionally, we found a substantial overlap with the language tasks in the supplementary motor area (SMA) and the premotor dorsal (PMD) both key structures for preparation and initiation of a voluntary action ${ }^{42}$, recently shown to be involved in the sense of agency - the feeling of controlling events through one's actions ${ }^{43}$. Such activations were evident in all self-generated verbal tasks employed in our study as well, such as word fluency and working memory (see figure 4C-E). These results are compatible with recent empiric evidence that inner speech - a purely mental action - is associated with an efference copy, previously associated only to overt movements, thus suggesting that inner speech may reflect a special type of overt speech ${ }^{44}$.

When examining the relationship of deactivations during AT in DMN regions compared to rest, we failed to find significant modulations compared to rest - either deactivations (figures $6 \& 7$ ), or activations. This argues against the view that abstract thinking is strongly based on enhanced activation of processes typically associated with the DMN, such as self-related cognition ${ }^{24,45}$, "metallization" ${ }^{22,23}$ or introspection ${ }^{32}$. 
It could be argued that comparing the AT condition to rest may have under-estimated the brain activation during AT since similar cognitive processes could have been generated during rest. In order to examine this possibility, we directly compared the rest and AT conditions by contrasting them with a language condition. Our results (figure S1) reveal major differences between the AT condition and rest, with higher activation during AT in frontal regions. Thus, although we cannot rule out the possible engagement of some AT during rest, the resulting brain activation during the two conditions was substantially different.

Notably, AT also activated the temporal pole which was not activated by any other task we tested. The temporal pole is suggested to be activated in integrating complex, highly processed perceptual inputs to visceral emotional responses ${ }^{46}$. This activation appears compatible with the abstract and high level cognitive processing involved in AT.

A recent fMRI study of spontaneously arising thoughts ${ }^{48}$ showed a set of regions similar to the AT network shown here, including the SMA, posterior cingulate cortex, IPL, temporal pole and superior temporal gyrus. This overlap may be attributed to the rather unconstrained nature of the AT tasks in the present study.

While examining the cortical networks associated with AT activation is important to revealing the cognitive components engaged during such thoughts, not less informative is examining those networks that were not activated during AT.

Comparing the AT activations to high order visual activation didn't show any overlap (figure 5A). Furthermore, the activation associated with visual imagery was clearly segregated from the AT activations (see figure $5 \mathrm{~F}-\mathrm{G}$ ). This result therefore argues against a role for high order visual regions and visual imagery in AT.

Another important cortical region that wasn't activated, was the posterior parietal cortex (PPC), known to be involved in many basic operations-such as spatial attention 49, mathematical cognition, working memory, long-term memory, coordinate transformation ${ }^{50}$, and language reviewed by 3 . However, given that evidence suggests that the PPC's contribution to thinking may be most closely related to its role in mathematical cognition rather than linguistic processing or spatial relations ${ }^{3,51}$, it is plausible that the abstract thoughts evoked in the present study did not activate such a probabilistic computation dependent on numerical processing mechanisms.

Of particular interest is the complete absence of enhanced activation in the parietal lobe areas of body representations e.g. 34 . Such failure argues against a straight-forward embodied cognition view, that the body functions as a constituent of high order cognitive processes ${ }^{52}$. Of particular relevance here is the suggestion that somatosensory and motor cortices activation constitute an integral part of thought processes ${ }^{53}$. It appears that at least for the kind of thought processes employed in abstract thinking, such somatosensory involvement was not required. 
Furthermore, comparing the level of similarity of each group of conditions to the AT with the neural distance analysis revealed a significantly higher similarity of the language tasks to the AT conditions (figure 8C). Thus, our quantitative analysis further supports the preferential overlap of AT to language-related functionality. However, it is important to emphasize that the activation patterns to AT showed a significant difference from purely language tasks (figure 8C).

To summarize, our results suggest that there is an abstract-thought left-lateralized network, involving regions relevant to language processing, volition, and likely intrinsic processing. Importantly, this network does not include somato-motor representations, or default network activation. Finally, this network is invariant to thought content and highly consistent across individuals.

\section{Methods}

\section{Participants}

Our study included twenty-three healthy participants (age $40 \pm 9.5$ years, 8 females) that underwent fMRI scanning. Pre-established inclusion criteria include right handedness by self-report, demographic variables (age, education level), fMRI safety criteria, and no history of neurological or mental health disorders (including no medication use). All participants provided written informed consent for their participation. Two participants did not fully comply with the task (see first-person reports in Table 1, marked by asterisks), due to conceptual mistakes: one forgot the precise AT1 instructions (\#7), and the other thought that the resting epoch is a continuation of AT1 (\#23). Thus, these two participant were excluded from further analyses. In addition, one participant (\#15) had missing neural data. Hence, only 20 participants are reported throughout the study, and all figures were adjusted accordingly. The sample size is well above the optimal number of participants suggested for fMRI studies, of about $16^{54}$. The experimental procedures were approved by the Ichilov hospital ethics committee.

\section{Imaging setup}

Images were acquired on a 3 Tesla Trio Magnetom Siemens scanner, at the Weizmann Institute of Science, Rehovot, Israel. Functional T2*-weighted images were obtained with gradient echo planar imaging (EPI) sequence $(\mathrm{TR}=3000 \mathrm{~ms}, \mathrm{TE}=30 \mathrm{~ms}$, flip angle $=90^{\circ}$, FOV $240 \mathrm{~mm}$, matrix size $80 \times 80$, scanned volume -46 axial slices tilted to the ACPC plane, of $3 \times 3 \times 3 \mathrm{~mm}$ voxels to cover the whole brain without gaps).

The participant's head was placed on a foam cushion for stabilization, and MR compatible earphones (MR confon, Magdeburg, Germany) that substantially reduce external noise were placed on the ears. Three-dimensional T1-weighted anatomical images were acquired to facilitate the incorporation of the functional data into the $3 \mathrm{D}$ Talairach space $(1 \times 1 \times 1 \mathrm{~mm}$ resolution, 3D MP-RAGE sequence, TR=2300 ms, TE=2.98 $\mathrm{ms}, \mathrm{TI}=900 \mathrm{~ms} / 9^{\circ}$ flip angle). 


\section{fMRI stimuli and experimental design}

The study consisted of three consecutive scans of approximately ten minutes in length (figure 1A, Table 2). Prior to each scan, participants received detailed instructions regarding the various tasks at each condition and were told which auditory cue signified each condition. Presentation ${ }^{\circledR}$ software (Neurobehavioral Systems, Inc.) was used to deliver the auditory stimuli via the MR-compatible headphones.

In the first and second scans (Thought 1 and 2), conducted with closed eyes, abstract thought (AT) was compared to both visual imagery, working memory and language tasks. These two scans were given in random order (15 performed first "Thought 1 " and 8 performed first "Thought 2", see Table 1). The first scan (figure 1B) included 4 tasks: i) AT1 task ("Is there free will?"), ii) a classical language task 'Sentences Conjugation', iii) a working memory task examining working memory engagement, and iv) a visual imagery condition ("imagine tools").

The second scan (figure 1C) included 3 tasks: i) the AT2 task ("Is man's nature good or evil?"), ii) a classical language task (verbal fluency), and iii) a visual imagery task ("imagine navigation").

Finally, in the last scan (figure 1D), each participant performed with their eyes open a Visual Categories, which was used to define the DMN regions for our group of participants, as previously reported ${ }^{55}$.

Immediately following each of the first three scans, each participant was interviewed while in the scanner via an intercom with a semi structured interview, in order to provide a brief description of the content of their experience. Particularly, participants were asked after the first and second scans to report feely the mental content during the abstract thought (AT), rest, and visual-imagery conditions - in order to make sure they were able to follow the instructions (especially important when no other behavioral measure was taken). For the AT conditions participants were also asked to rate the level of internal speech, internal visualization and interest on a five-point scale $(1=$ very low to $5=$ very high). For the VF they were asked to count the generated words.

\section{Pre-processing and statistical data Analysis}

fMRI Data were analyzed with brain-voyager QX and matlab 2014b with the Neuroelf toolbox version 0.9 . The functional images were incorporated into the $3 \mathrm{D}$ data sets through trilinear interpolation. Preprocessing of functional scans included 3D motion correction, filtering out of low frequencies (high pass) up to 2 cycles per scan (slow drift), and spatial smoothing using a Gaussian kernel with a full width at half maximum of $6 \mathrm{~mm}$.

Segments showing movement artifacts larger than $1 \mathrm{~mm}$ or sharp head movements were excluded from the analysis. The cortical surface in a Talairach coordinate system ${ }^{56}$ was reconstructed for each participant from the 3D-spoiled gradient echo scan. The functional images were then superimposed on 2D anatomic images and incorporated into the $3 \mathrm{D}$ data sets through trilinear interpolation. 
Statistical analysis was based on the general linear model (GLM), performed separately for each participant and for each scan with a regressor for each condition, excluding the rest epochs. All regressors were modeled as box-car functions convolved with the hemodynamic response function. In order to account for non-neuronal contributions to the BOLD signal, six null predictors were added to the analysis, corresponding to head motion in the relevant axes 3 translational and 3 rotational vectors). The analysis was performed independently for the time-course of each individual voxel.

The multi-participant functional maps were projected on an inflated or unfolded Talairach normalized brain. Significance levels were calculated, taking into account the minimum cluster size and the probability threshold of a false detection of any given cluster. This was accomplished by a Monte-Carlo simulation (cluster-level statistical threshold estimator in "Brain-voyager"), targeting a threshold of $\mathrm{p}<.05$ corrected (using 1500 iterations). The probability of a false positive detection per image was determined from the frequency count of cluster sizes within the entire brain. For the AT1 v. rest a minimum cluster size of 16 voxels was significant, for AT2 vs. rest - 12 voxels, AT2 vs. Sentences Conjugation - 12 voxels, Imagine Navigation vs. rest - 18 voxels, Imagine Tools vs. rest - 19 voxels, AT1 vs. Verbal Fluency - 17 voxels, Verbal Fluency vs. rest 25 voxels, Visual Categories vs. rest -31 voxels, Sentences Conjugation vs. rest - 29 voxels, Working Memory vs. rest - 32 voxels, rest vs. Sentences Conjugation - 28 voxels. For presentation purposes we used the value 25 as cluster threshold for the maps of the first six contrasts, and cluster threshold of 32 voxels for the last four contrasts.

For each participant and a given ROI we extracted the mean time course across all ROI voxels and calculated the event-related averaged response for the conditions in each scan. The signal was normalized to percent signal change relative to a baseline which was defined as the average value of the 2 TRs prior to the stimulus. Additionally, using the results from the GLM, we calculated the mean beta value for each ROI and participant separately. The comparison between the beta values in the two AT scans was done using two-tailed $t$-test, Bonferroni corrected for multiple comparisons.

\section{Neural pattern classifier}

In order to perform neural pattern classification, we conducted "Leave one out" analysis. This was performed for five bulk conditions, lumping together for each participant the average betas of the two thought conditions, the two language conditions, the working memory task, the two imagery conditions and the four visual conditions. Then, in order to avoid highly unreliable voxels, which may introduce noise to the analysis, we performed again the analyses (as previously done by ${ }^{57}$; and by ${ }^{58}$ ), this time including only the $50 \%$ of total voxels with lowest variability. We calculated the correlation coefficients per participant and mean group betas (not including the "leave" participant). This allowed us to classify for each participant the task with highest correlation coefficient; correct classifications were considered highest correlation with 
AT bulk conditions. Percent participants resulting with correct classification was calculated. This was performed for the whole cortex (100\% cortical voxels) and $50 \%$ low variability voxels.

For the individual tasks classification, in order to calculate the statistical significance, we randomly permuted the tasks in each participant and calculated the correlations coefficients with the mean of the group as described above, this was repeated $10 \mathrm{k}$ times. This allowed us to evaluate the probability to achieve such classification by chance, with lower than $5 \%$ considered significant.

\section{Neuronal distance metric}

In order to further probe the relationship between abstract thought and other tasks aside from overlap of univariate activity, we added a Neuronal Distance Analyses. In this analyses, a vector was constructed by concatenating the mean beta values for each voxel (across the entire cortex) in each participant and each condition. The neural distance between 2 tasks for the same participant was defined as the Euclidean distance between the corresponding task vectors, similar as in other studies ${ }^{57,59}$.

Correlation coefficients were calculated per participant between beta vectors for each pair of conditions to produce the pair-wise distance matrix (higher correlation coefficient - shorter distance). The average distance matrix of all participants is displayed $(n=20$, figure S1). Average \pm SEM correlation coefficients between abstract thought conditions (thought 1 and thought 2) and any other condition were shown in the bar histograms (Figure 8). Paired t-tests were performed between the correlation coefficient of AT1 and AT2 compared to the correlations between thought 1 and the other conditions. (figure 8A, and figure $8 \mathrm{~B}$ respectively). Regarding the issue of multiple-comparisons, it should be noted that the critical comparison is between the thoughts and the language activations so basically we have two comparisons (and all the other are given for reference). To minimize this concern, we also acquired five bulk conditions, lumping together for each participant the average correlation coefficient of the two thought conditions, the two language conditions (regarding the language working memory task as a different category), the two imagery conditions and the four visual conditions (figure 8A\&B). Average \pm SEM correlation coefficients between abstract thought conditions and the other conditions are also shown in the bar histogram (figure 8C).

\section{Inter-participant variability}

In order to estimate the inter-participant variability in the different conditions, for each condition whole brain mean beta vector (cortex only) was calculated and correlation coefficient of each participant to the mean beta was calculated.

\subsection{Definitions of ROIs}

In all the ROI analyses described, ROIs of activation were defined for each participant individually, as the activated voxels located within $10^{\wedge} 3 \mathrm{~mm}$ around the activation/deactivation peaks, as will be described below. A functional ROI approach in 
which the region is first identified functionally in each participant individually was chosen because functional properties are more consistently associated with functional ROIs than with locations in stereotaxic space, and is best suited to test functional hypotheses ${ }^{60,61}$.

Language ROIs, the L-Broca and L-IFG were defined from the sentence-conjugation task, as the activated voxels located within $10^{\wedge} 3 \mathrm{~mm}$ of the activity center. DMN ROIs were selected based on resting-state functional connectivity. The seed for the functionalconnectivity analysis was the left precuneus (Prc), defined from the Visual Categories scan as the voxels within $10^{\wedge} 3 \mathrm{~mm}$ around the point of highest deactivation in the respective anatomical region, confirmed using an Atlas ${ }^{62}$. The other DMN ROIs, right Prc and the bilateral posterior part of inferior parietal lobule (IPL), were identified by lowering the threshold of the functional connectivity map and choosing the highest functionally connected respective regions which appear in specific anatomical locations (thus ensuring the correct selection of DMN regions using both functional and anatomical criteria). The network maps were inspected individually and compared between participants to ensure that the ROIs did not considerably vary anatomically. We found for the L-Prc that the inter-individual differences across participants did not exceed 15 voxels (mean of 6 voxels).

\section{Availability statement}

All the data is publically available at the following link

https://drive.google.com/drive/folders/1KzA7Bo1otaEEhBykan1v41_KTDeNBxL7? $\underline{\text { usp}}=$ sharing

\section{Code availability}

All the custom codes are publically available at the following link

https://drive.google.com/drive/folders/1KzA7Bo1otaEEhBykan1v41_KTDeNBxL7? $\underline{\mathrm{usp}}=$ sharing

\section{Acknowledgements}

The study was funded by the Helen and Kimmel Award for innovative Research, The EU (FP7 VERE), The EU - Human Brain Project and the ISF-ICORE grants to Prof. R. Malach, and the Teva Pharmaceutical Industries LTD fellowship to Dr. A. BerkovichOhana. Dr. E. Furman-Haran holds the Calin and Elaine Rovinescu Research Fellow Chair for Brain Research. 


\section{$\underline{\text { References }}$}

1. Killingsworth, M. A. \& Gilbert, D. T. A wandering mind is an unhappy mind. Science 330, 932-932 (2010).

2. Smallwood, J. \& Schooler, J. W. The restless mind. Psychol. Bull. 132, 946-958 (2006).

3. Wendelken, C. Meta-analysis: how does posterior parietal cortex contribute to reasoning? Front. Hum. Neurosci. 8, 1042-1042 (2013).

4. Piaget, J. \& Inhelder, B. The growth of logical thinking from childhood to adolescence: An essay on the construction of formal operational structures. 84, (Routledge, 2013).

5. Neural correlates of thinking. (Springer, 2009).

6. Gleitman, L. \& Papafragou, A. Language and thought. in Cambridge handbook of thinking and reasoning (eds. Holyoak, K. J. \& Morrison, R. G.) 633-661 (Cambridge University Press, 2005).

7. Sokolov, A. Inner speech and thought. (Plenum Press, 1972).

8. Dove, G. Thinking in words: language as an embodied medium of thought. Top. Cogn. Sci. 6, 371-389 (2014).

9. Slobin, D. I. Language and thought online: Cognitive consequences of linguistic relativity. in Language in mind: Advances in the study of language and thought 157192, (2003).

10. Whorf, B. L. Language, thought, and reality: Selected writings of Benjamin Lee Whorf. (Mit Press, 2012).

11. Mental logic. (Erlbaum, 1998). 
12. Carruthers, P. The cognitive functions of language. Behav. Brain Sci. 25, 657-674 (2002).

13. Kertesz, A. \& McCabe, P. Intelligence and aphasia: performance of aphasics on Raven's coloured progressive matrices (RCPM). Brain Lang. 2, 387-395 (1975).

14. Pinker, S. The Language Instinct: How the Mind Creates Language. (Penguin UK, 2003).

15. Wang, J., Conder, J. A., Blitzer, D. N. \& Shinkareva, S. V. Neural representation of abstract and concrete concepts: A meta $\square$ analysis of neuroimaging studies. Hum. Brain Mapp. 31, 1459-1468 (2010).

16. Sans-Sansa, B. et al. Association of formal thought disorder in schizophrenia with structural brain abnormalities in language-related cortical regions. Schizophr. Res. 146, 308-313 (2013).

17. Perrone-Bertolotti, M., Rapin, L., Lachaux, J.-P., Baciu, M. \& Loevenbruck, H. What is that little voice inside my head? Inner speech phenomenology, its role in cognitive performance, and its relation to self-monitoring. Behav. Brain Res. 261, 220-239 (2014).

18. Johnson-Laird, P. N. Mental models: Towards a cognitive science of language, inference, and consciousness. (Harvard University Press, 1983).

19. Johnson-Laird, P. N. Mental models and deduction. Trends Cogn. Sci. 5, 434-442 (2001).

20. Quiroga, R. Q. Concept cells: the building blocks of declarative memory functions. Nat. Rev. Neurosci. 13, 587-597 (2012). 
21. Gilead, M., Liberman, N. \& Maril, A. From mind to matter: neural correlates of abstract and concrete mindsets. Soc. Cogn. Affect. Neurosci. 9, 638-645 (2014).

22. Spunt, R. P. \& Lieberman, M. D. Dissociating modality-specific and supramodal neural systems for action understanding. J. Neurosci. 32, 3575-3583 (2012).

23. Spunt, R. P., Falk, E. B. \& Lieberman, M. D. Dissociable neural systems support retrieval of how and why action knowledge. Psychol. Sci. 1593-1598 (2010).

24. Golland, Y. et al. Extrinsic and intrinsic systems in the posterior cortex of the human brain revealed during natural sensory stimulation. Cereb. Cortex 17, 766-777 (2007).

25. Raichle, M. E. et al. A default mode of brain function. Proc. Natl. Acad. Sci. U. S. A. 98, 676-682 (2001).

26. Chatterjee, A. \& Vartanian, O. Neuroscience of aesthetics. Ann. N. Y. Acad. Sci. 1369, 172-194 (2016).

27. Glasser, M. F. et al. The human connectome project's neuroimaging approach. Nat. Neurosci. 19, 1175-1187 (2016).

28. Wager, T. D. \& Yarkoni, T. Establishing homology between monkey and human brains. Nat. Methods 9, 237-239 (2012).

29. Hasson, U., Nir, Y., Levy, I., Fuhrmann, G. \& Malach, R. Intersubject synchronization of cortical activity during natural vision. Science 303, 1634-1640 (2004).

30. Friederici, A. D. The brain basis of language processing: from structure to function. Physiol. Rev. 91, 1357-1392 (2011). 
31. Yellin, D., Berkovich-Ohana, A. \& Malach, R. Correlations between pupillary and fMRI BOLD timecourses uncover antagonistic relationship between high and low order visual areas during rest and imagery. NeuroImage 106, 414-427 (2015).

32. Goldberg, I. I., Harel, M. \& Malach, R. When the brain loses its self: Prefrontal inactivation during sensorimotor processing. Neuron 50, 329-339 (2006).

33. Becker, J. T., MacAndrew, D. K. \& Fiez, J. A. A comment on the functional localization of the phonological storage subsystem of working memory. Brain Cogn. 41, 27-38 (1999).

34. Amedi, A., Malach, R. \& Pascual-Leone, A. Negative BOLD differentiates visual imagery and perception. Neuron 48, 859-872 (2005).

35. Sharma, N. \& Baron, J.-C. Does motor imagery share neural networks with executed movement: a multivariate fMRI analysis. Front. Hum. Neurosci. 7, (2013).

36. Wei, G. \& Luo, J. Sport expert's motor imagery: functional imaging of professional motor skills and simple motor skills. Brain Res. 1341, 52-62 (2010).

37. Fletcher, P. C. et al. The mind's eye-precuneus activation in memory-related imagery. NeuroImage 2, 195-200 (1995).

38. Mühlau, M. et al. Left inferior parietal dominance in gesture imitation: an fMRI study. Neuropsychologia 43, 1086-1098 (2005).

39. Chaminade, T. \& Decety, J. Leader or follower? Involvement of the inferior parietal lobule in agency. Neuroreport 13, 1975-1978 (2002).

40. Friederici, A. D. \& Chomsky, N. Language in our Brain: The Origins of a Uniquely Human Capacity. (MIT Press, 2017). 
41. Berwick, R. C., Friederici, A. D., Chomsky, N. \& Bolhuis, J. J. Evolution, brain, and the nature of language. Trends Cogn. Sci. 17, 89-98 (2013).

42. Nachev, P., Wydell, H., O’Neill, K., Husain, M. \& Kennard, C. The role of the pre-supplementary motor area in the control of action. NeuroImage 36, T155-T163 (2007).

43. Moore, J. W., Ruge, D., Wenke, D., Rothwell, J. \& Haggard, P. Disrupting the experience of control in the human brain: pre-supplementary motor area contributes to the sense of agency. Proc. R. Soc. Lond. B Biol. Sci. rspb20100404 (2010).

44. Whitford, T. J. et al. Neurophysiological evidence of efference copies to inner speech. eLife e28197 (2017).

45. Preminger, S., Harmelech, T. \& Malach, R. Stimulus-free thoughts induce differential activation in the human default network. NeuroImage 54, 1692-1702 (2011).

46. Olson, I. R., Plotzker, A. \& Ezzyat, Y. The enigmatic temporal pole: a review of findings on social and emotional processing. Brain 130, 1718-1731 (2007).

47. Berlin, H. A., Rolls, E. T. \& Kischka, U. Impulsivity, time perception, emotion and reinforcement sensitivity in patients with orbitofrontal cortex lesions. Brain 127, 1108 (2004).

48. Ellamil, M. et al. Dynamics of neural recruitment surrounding the spontaneous arising of thoughts in experienced mindfulness practitioners. Neuroimage 136, 186196 (2016).

49. Corbetta, M. \& Shulman, G. L. Control of goal-directed and stimulus-driven attention in the brain. Nat. Rev. Neurosci. 3, 215-229 (2002). 
50. Culham, J. C. \& Valyear, K. F. Human parietal cortex in action. Curr. Opin.

Neurobiol. 16, 205-212 (2006).

51. Dehaene, S., Spelke, E., Pinel, P., Stanescu, R. \& Tsivkin, S. Sources of mathematical thinking: Behavioral and brain-imaging evidence. Science 284, 970-974 (1999).

52. Leitan, N. D. \& Chaffey, L. Embodied cognition and its applications: A brief review. Sensoria J. Mind Brain Cult. 10, 3-10 (2014).

53. Gallese, V. \& Lakoff, G. The brain's concepts: The role of the sensory-motor system in conceptual knowledge. Cogn. Neuropsychol. 22, 455-479 (2005).

54. Friston, K. Ten ironic rules for non-statistical reviewers. Neuroimage 61, 13001310 (2012).

55. Berkovich-Ohana, A., Harel, M., Hahamy, A., Arieli, A. \& Malach, R. Alterations in Task-induced activity and resting-state fluctuations in visual and DMN areas revealed in long-term meditators. NeuroImage 135, 125-134 (2016).

56. Talairach, J. \& Tournoux, P. Co-planar stereotaxic atlas of the human brain. 3Dimensional proportional system: an approach to cerebral imaging. (Thieme Medical Publishers, 1988).

57. Davidesco, I. et al. Exemplar Selectivity Reflects Perceptual Similarities in the Human Fusiform Cortex. Cereb. Cortex 24, 1879-1893 (2014).

58. Mukamel, R. et al. Coupling between neuronal firing, field potentials, and FMRI in human auditory cortex. Science 309, 951-954 (2005).

59. Wilf, M. et al. Spontaneously Emerging Patterns in Human Visual Cortex Reflect Responses to Naturalistic Sensory Stimuli. Cereb. Cortex 1, 14 (2015). 
60. Saxe, R., Brett, M. \& Kanwisher, N. Divide and conquer: a defense of functional localizers. NeuroImage 30, 1088-1096 (2006).

61. Hahamy, A., Behrmann, M. \& Malach, R. The idiosyncratic brain: distortion of spontaneous connectivity patterns in autism spectrum disorder. Nat. Neurosci. 18, 302-309 (2015).

62. Duvernoy, H. M. The Human Brain: Surface, Blood Supply, and Three-

Dimensional Sectional Anatomy. (Springer Wien New-York, 2001). 


\section{Figures for paper}

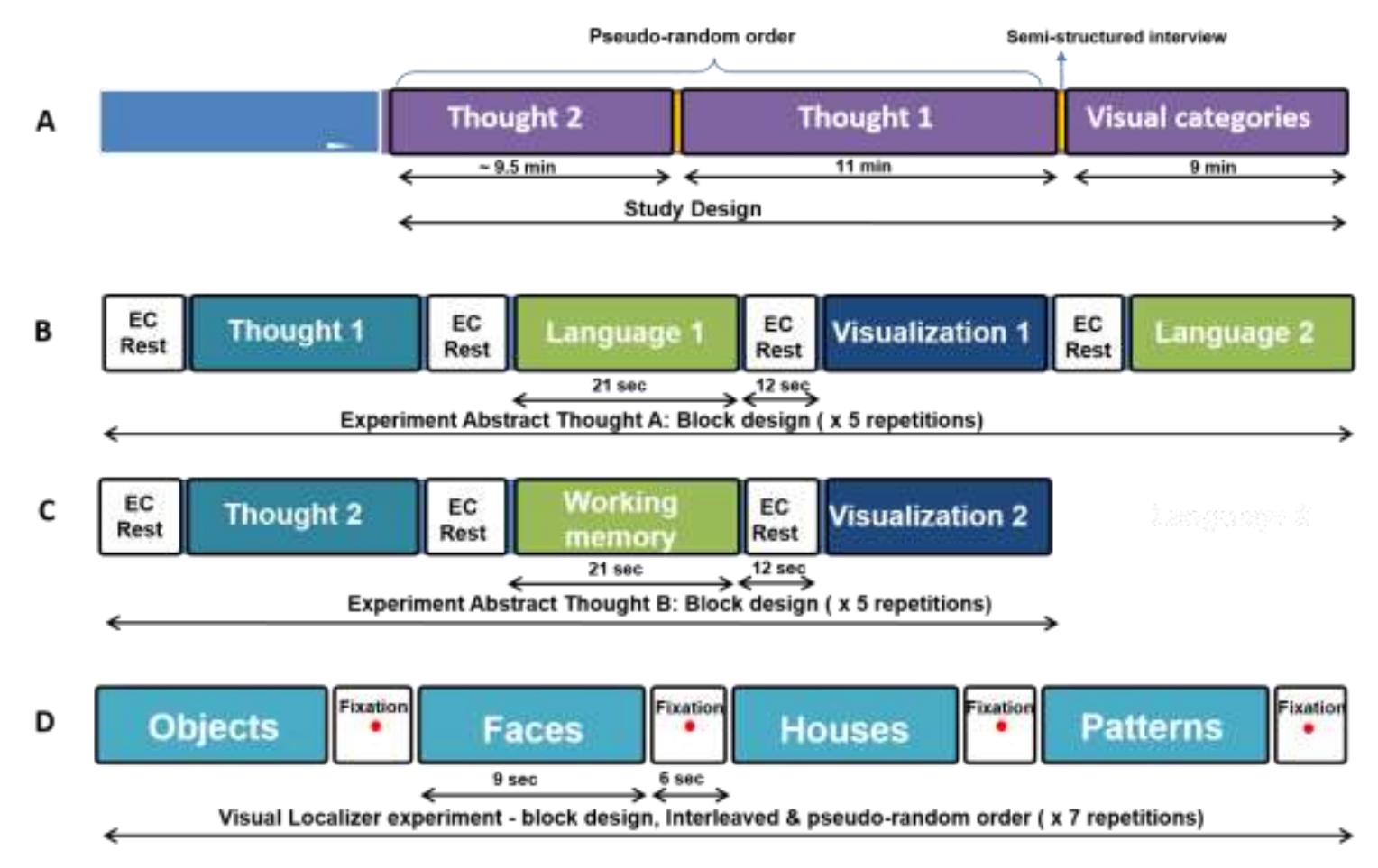

Figure 1: Study design. A. The study consisted of three consecutive scans. B. Describes the first scan, named "Abstract-thought A": "EC" denoted eyes closed; "Thought 1" denotes the thought "Is there free will?"; "Language 1" denotes Sentences Conjugation task; "Visualization 1" denotes Imagine Tools task; "Working memory" denotes Working Memory task. C. Describes the second scan, named "Abstractthought B": "Thought 2" denotes the thought "Is man's nature good or evil?"; "Language 3" denotes Verbal Fluency task; "Visualization 2" denotes Imagine Navigation task. D. Describes the third scan, which includes the Visual Categories task. Purple denotes scans; Turquoise denotes abstract-thought tasks; Green denotes language-related tasks; Dark blue denotes visual-imagery tasks; Light blue denotes visual stimulation tasks. 
A
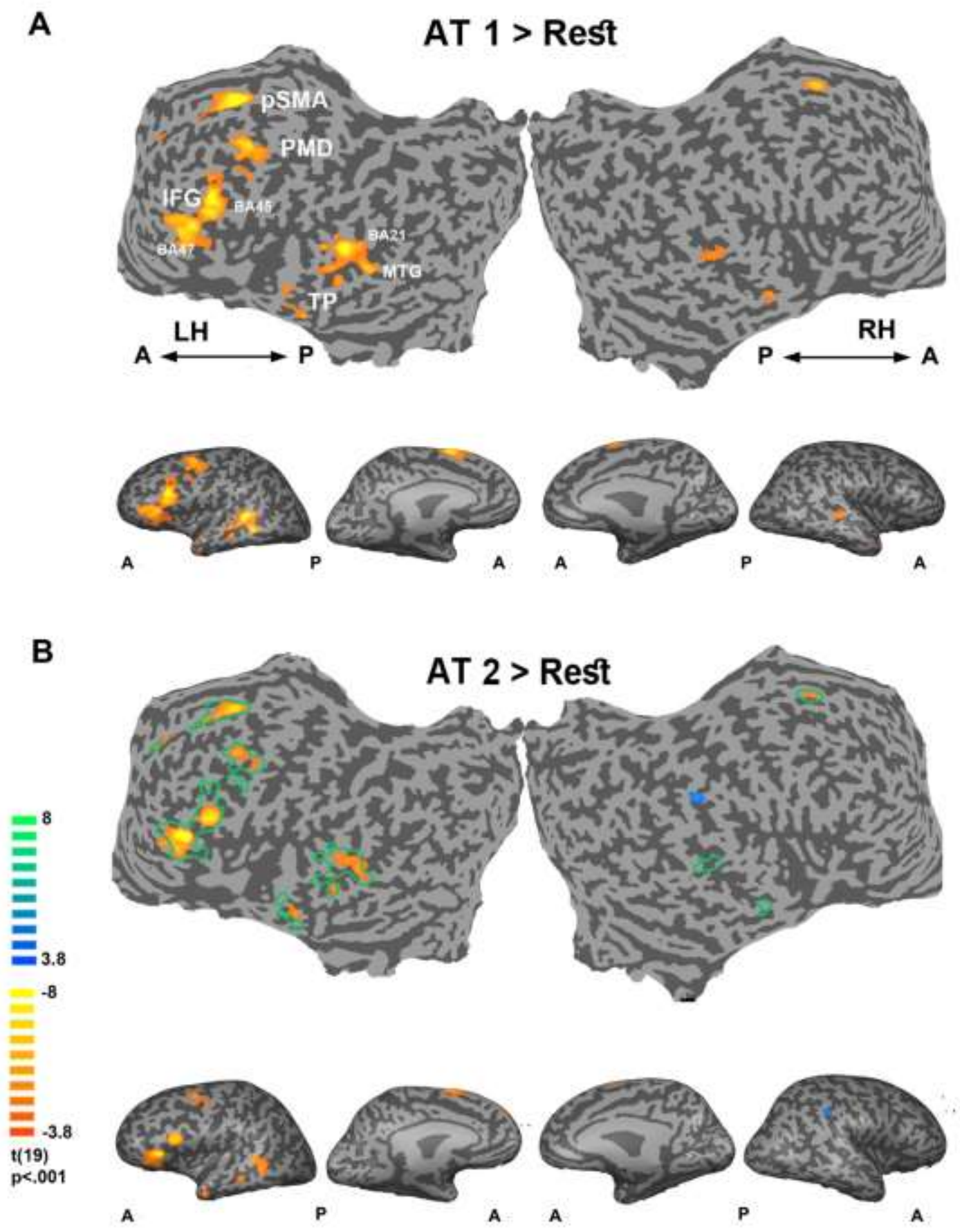

Figure 2: Average group activation during the abstract thought conditions (multi-subject randomeffect GLM analysis, $n=20$, Monte Carlo corrected). A. Comparing abstract-thought 1 (AT1 - "is there free will?") to rest, and B. Comparing AT2 ("is man's nature good or evil?") to rest. Unfolded (top) and inflated (bottom) views. Color bar indicates activations in yellow, and deactivations in blue. Green contours of the AT1 activations are superimposed on the AT2 activations. Note the remarkable similarity in the activations to the two AT topics. LH - left hemisphere; RH - right hemisphere; A - anterior; P - posterior; pSMA - pre supplementary motor area; PMD - pre motor dorsal; IFG - inferior frontal gyrus; BA Brodmann area; MTG - middle temporal gyrus; FP - Fronto-polar. 


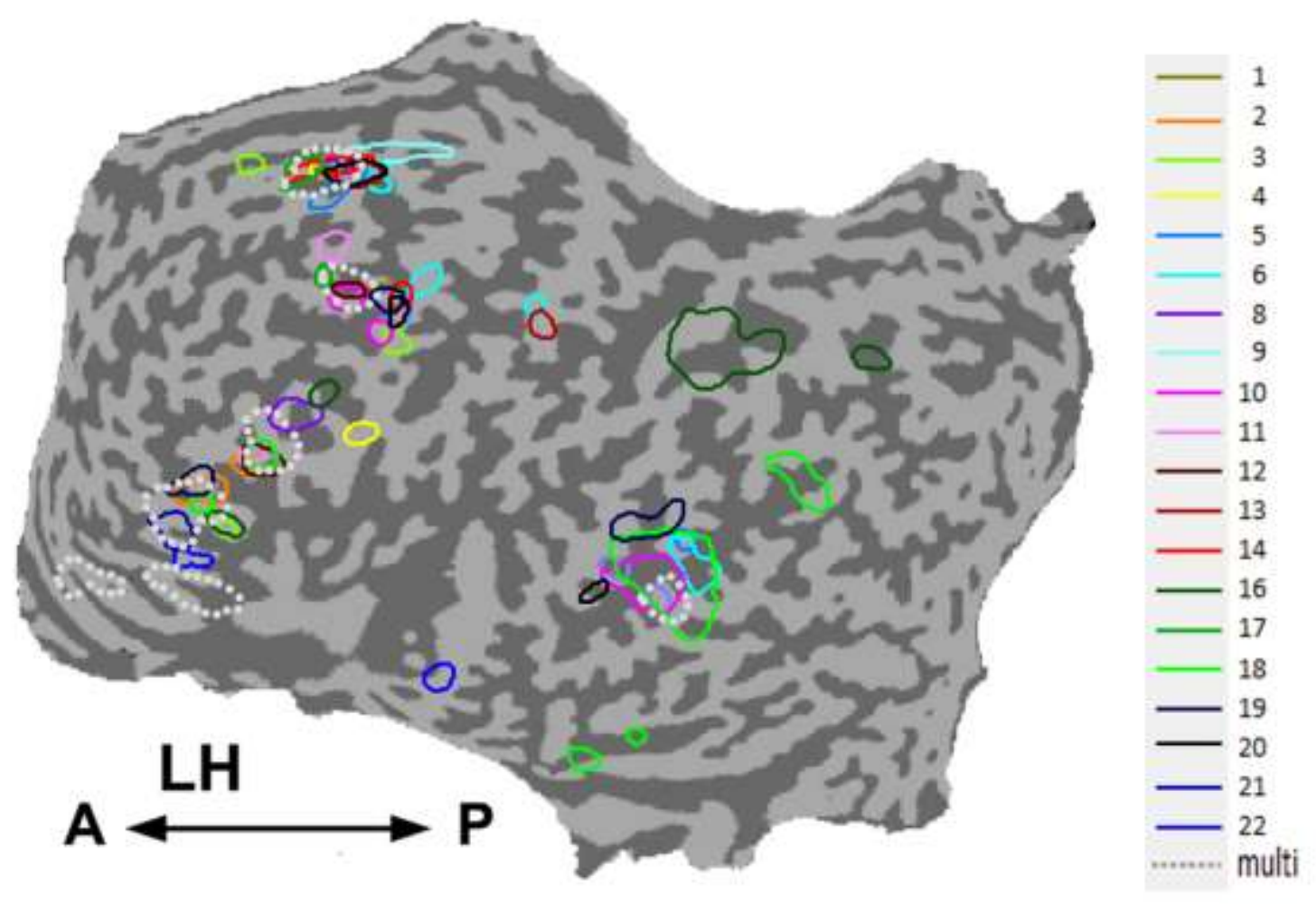

Figure 3: Level of Inter-subject Variability in the left hemisphere in the Abstract Thought 1 task $(n=$ 20). The statistical threshold for each participant is $>0.5 \%$ activation. Borders of cortical areas were superimposed on unfolded left hemisphere to assess their intersubject variability during the AT1. Colored lines represent boundaries of activated regions for each participant. Note the clustering of activation foci around similar cortical regions. LH, left hemisphere; A, anterior; P, posterior. 


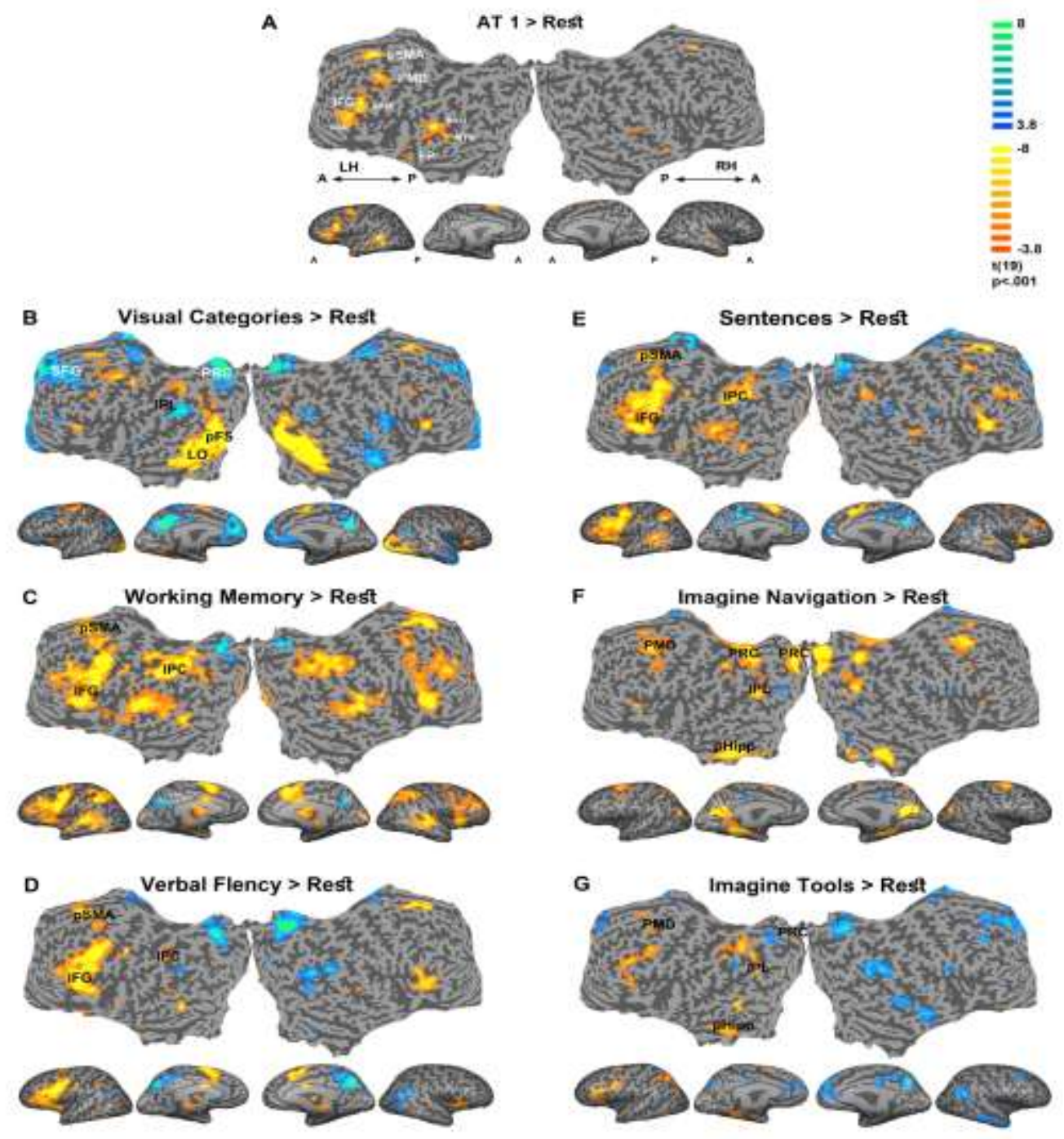

Figure 4: Whole brain maps of activations during the AT 1 and all the other tasks relative to rest (multisubject random-effect GLM analysis, $n=20$, Monte Carlo corrected). A. Abstract-thought 1 ("is there free will?"); B. Visual Categories scan: all visual stimuli grouped (four-categories: faces, houses, objects, and patterns); C. Working Memory task; D. Verbal Fluency; E. Sentences Conjugation task; F. Imagine Navigation task; G. Imagine Tools task. Color bar indicates activations in yellow, and deactivations in blue. Note the substantial overlap in activations during the AT condition and the language related ones. Unfolded views: LH - left hemisphere; RH - right hemisphere; A - anterior; P - posterior. pSMA - pre supplementary motor area; PMD - pre motor dorsal; IFG - inferior frontal gyrus; IPC - inferior parietal cortex; SFG superior frontal gyrus; IPL - inferior parietal lobule; PRC - precuneus; pFs - posterior fusiform; LO lateral occipital; IPC- inferior parietal cortex; pHipp - para Hippocampus. 


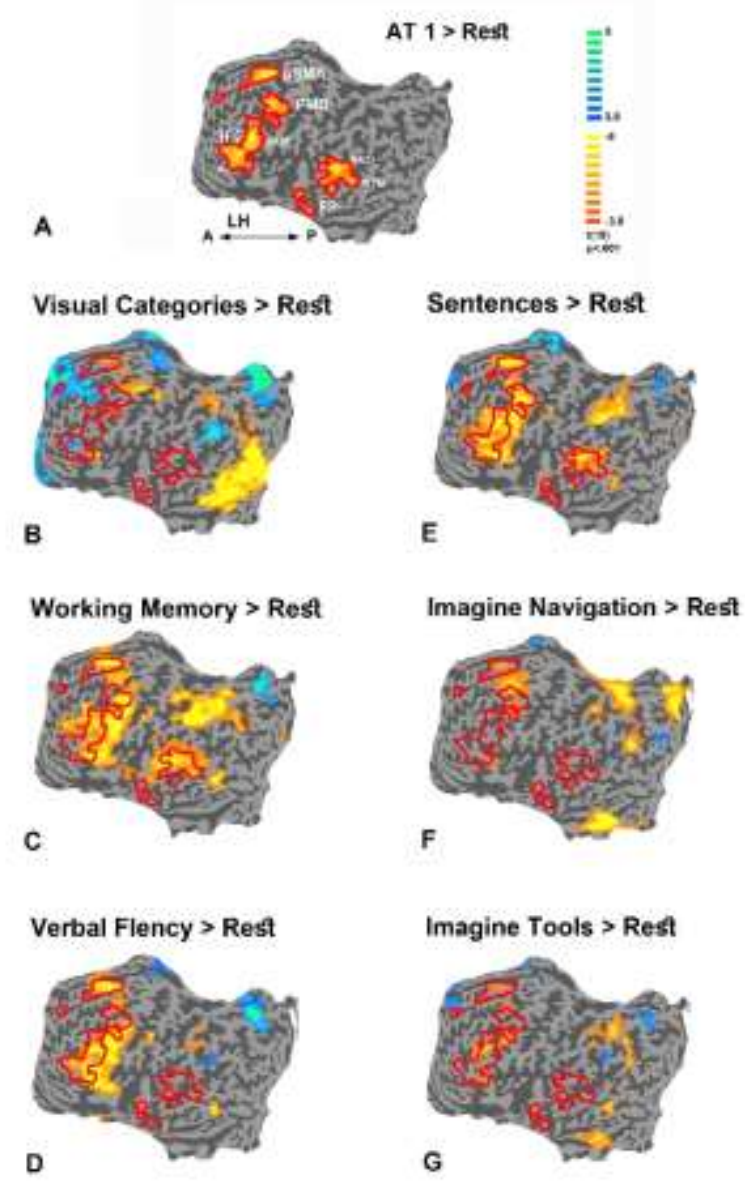

Figure 5: Overlap and segregations of the Abstract thought 1 activations. To examine possible overlaps and segregations of the AT1 activations from the other conditions, the boundaries of AT1 activations were marked by red contours and were superimposed on the other conditions (multi-subject random-effect GLM analysis, $n=20$, Monte Carlo corrected). A. Abstract-thought 1 vs. rest; B. Visual Categories scan vs. rest; C. Working Memory task vs. rest; D. Verbal Fluency vs. rest; E. Sentences Conjugation task vs. rest; F. Imagine Navigation task vs. rest; G. Imagine Tools task vs. rest. Color bar indicates activations in yellow, and deactivations in blue. Unfolded views: LH - left hemisphere; A - anterior; P - posterior. 

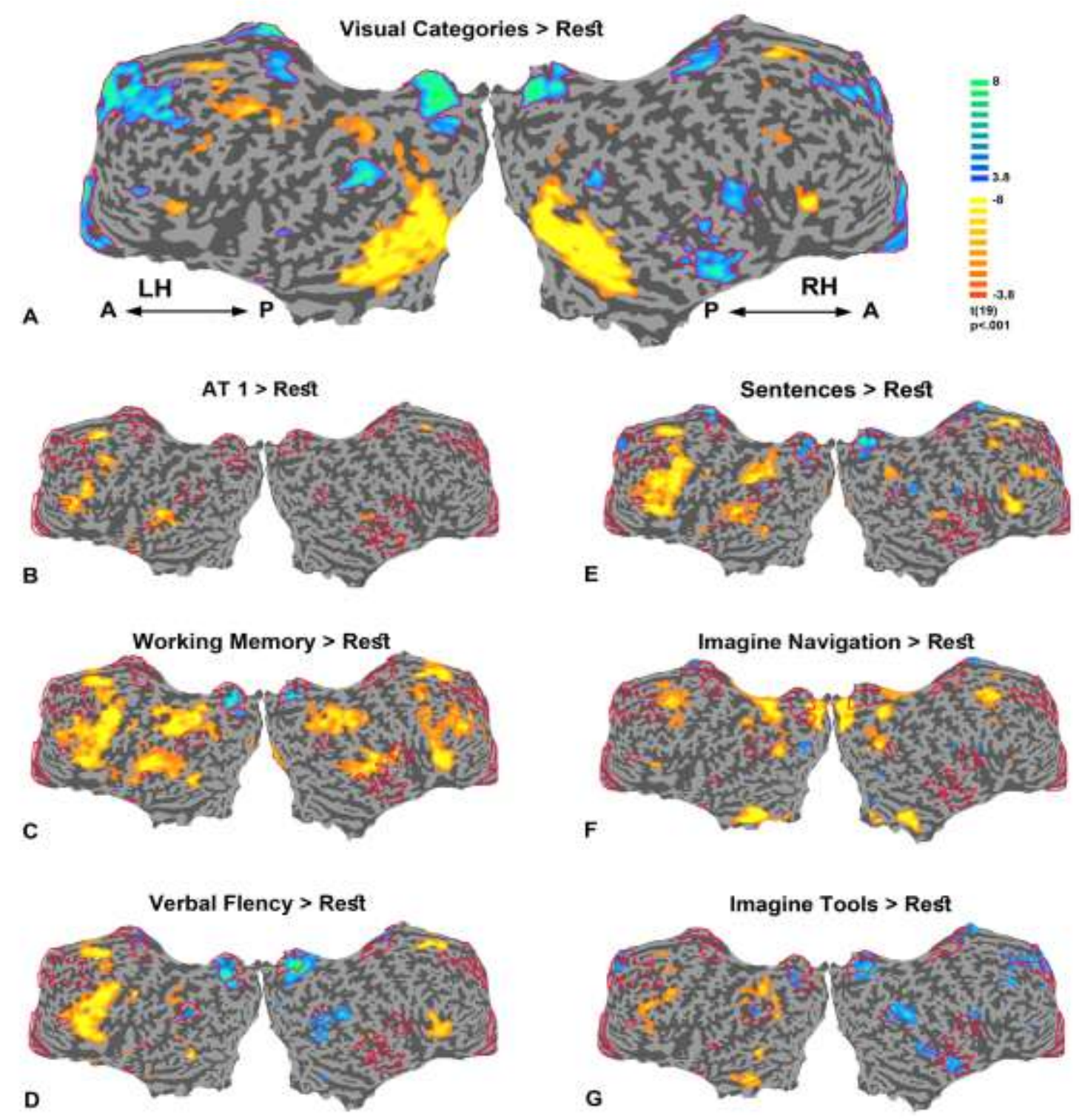

Figure 6: DMN deactivations (marked by red contours) superimposed on the other conditions. A. Visual Categories scan vs. rest; B. Abstract-thought 1 vs. rest; C. Working Memory task vs. rest; D. Verbal Fluency vs. rest; E. Sentences Conjugation task vs. rest; F. Imagine Navigation task vs. rest; G. Imagine Tools task vs. rest. Color bar indicates activations in yellow, and deactivations in blue (multi-subject random-effect GLM analysis, $n=20$, Monte Carlo corrected). Unfolded views: LH - left hemisphere; RH - right hemisphere; A - anterior; $\mathrm{P}$ - posterior. 
Visual Categories

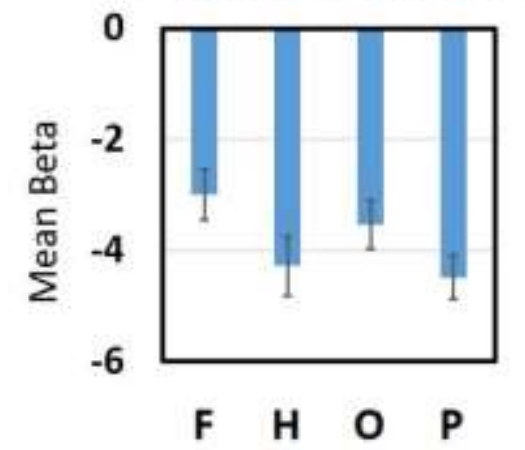

AT1

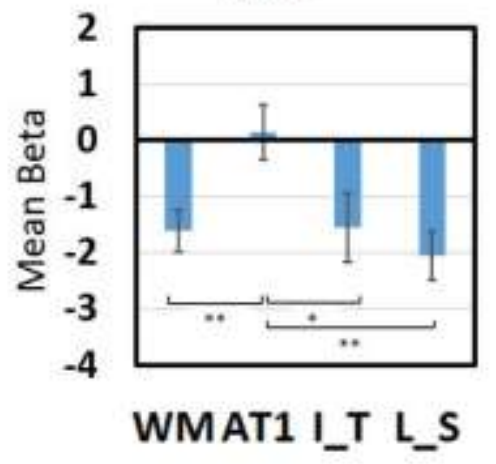

AT2

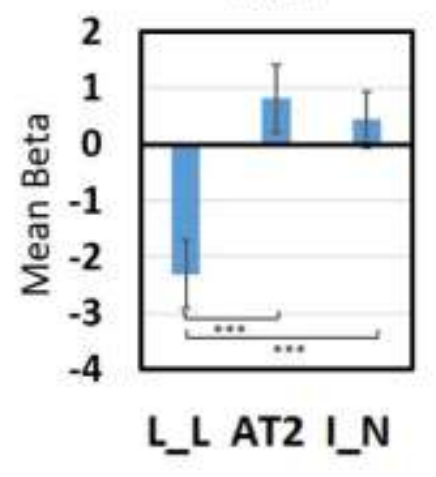

Figure 7: Mean beta values of average DMN ROI. Mean (M \pm SEM) beta values (from 4 DMN regions, $n$ $=20$ ) are shown for the three scans separately (from left to right: Visual Categories, Abstract-thought 1 and 2). F- face; $\mathrm{H}$ - house; $\mathrm{O}$ - objects; $\mathrm{P}$ - patterns; WM - Working Memory; AT1 - abstract thought 1; I_T Imagine Tools; L_S - language sentences conjugation; L_L - language letters (Verbal Fluency); AT2abstract thought 2; I_N - Imagine Navigation. Bonfferoni corrected $\mathrm{p}$ values: $* \mathrm{p}<.05 ; * * \mathrm{p}<.005 ;{ }^{* * *} \mathrm{p}$ $<.0005$. 

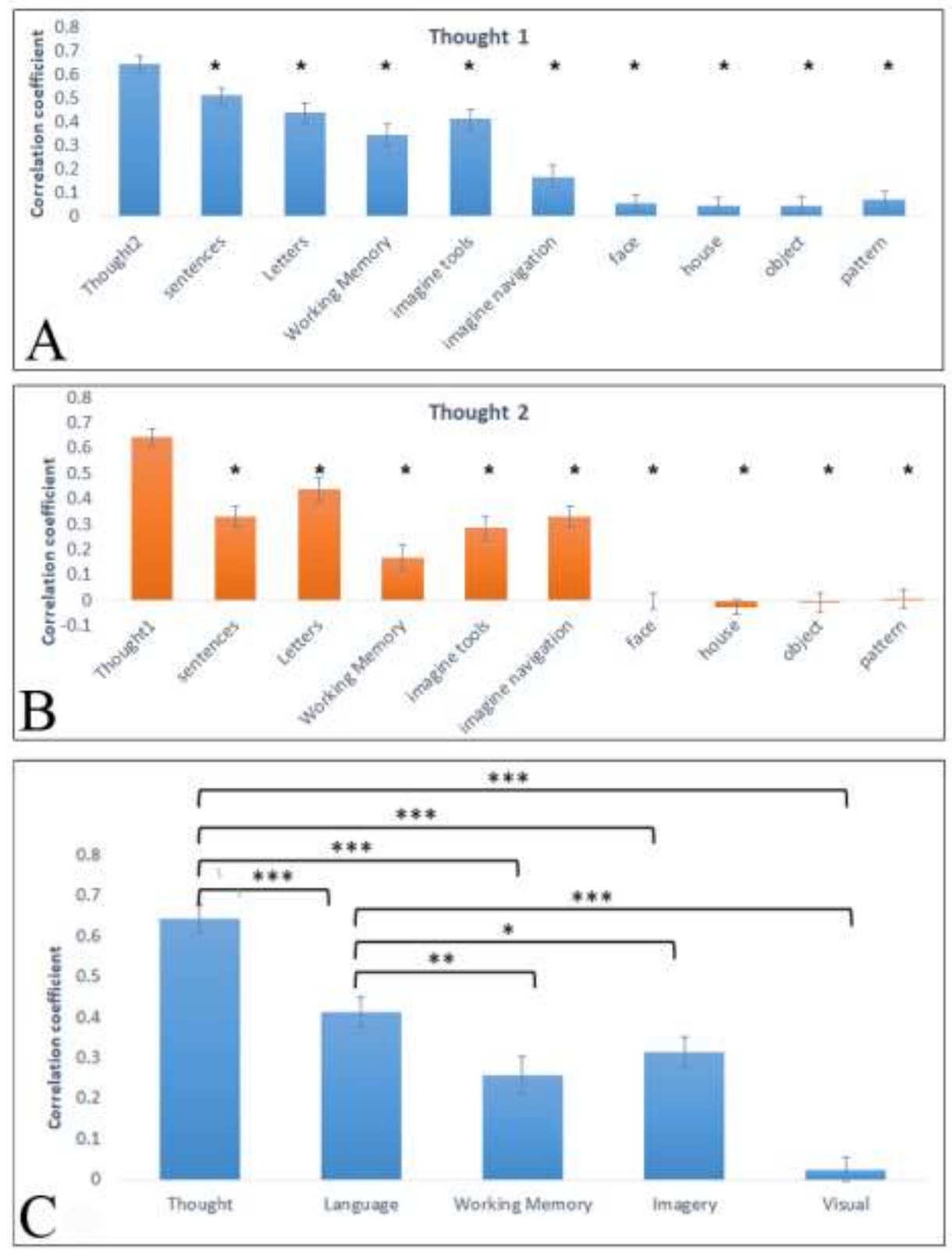

Figure 8: Neuronal Distance Analyses as bar histograms. Mean \pm SEM of correlation coefficients $(n=20)$ between all the conditions and A. AT1 (Figure 2A); and B. AT2 (Figure 2B). C. To reduce multiple comparisons, we lumped together the results of the two thought conditions, the two language conditions, the two imagery conditions and the four visual conditions. ${ }^{*} p<0.05 ;^{* *} p<0.0005 ; * * *<0.00005$. 
bioRxiv preprint doi: https://doi.org/10.1101/546085; this version posted February 10, 2019. The copyright holder for this preprint (which was not certified by peer review) is the author/funder, who has granted bioRxiv a license to display the preprint in perpetuity. It is made available under aCC-BY-NC-ND 4.0 International license.

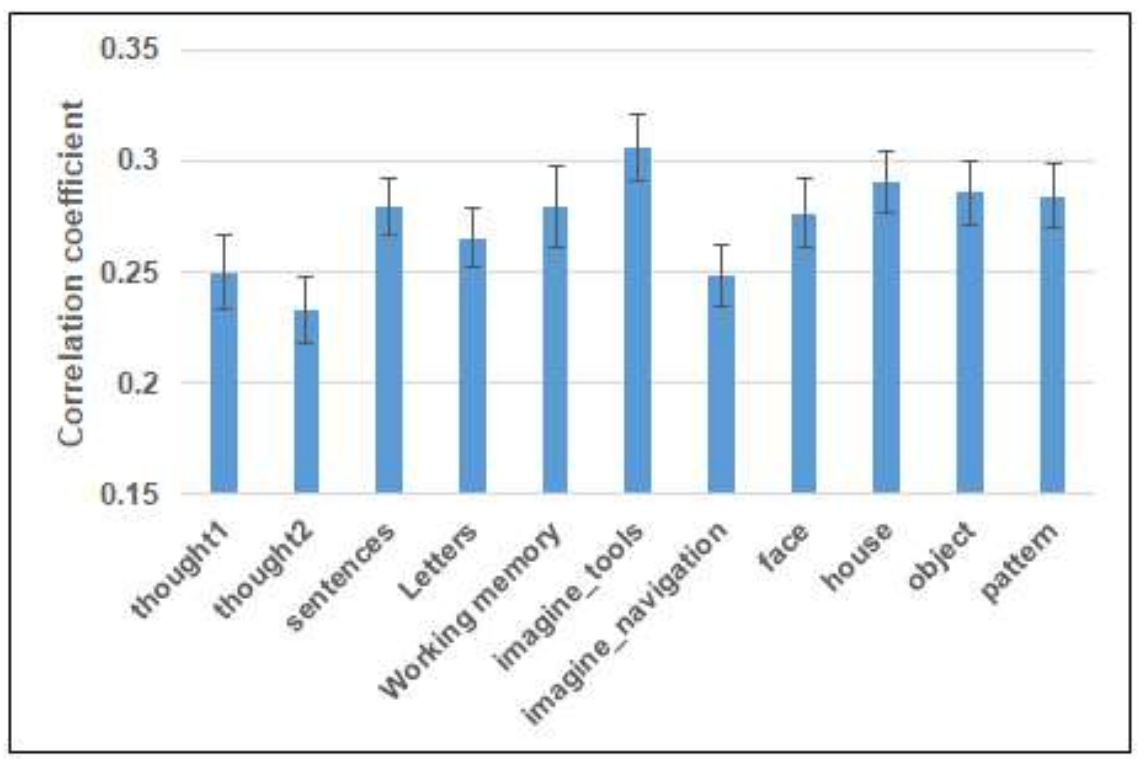

Figure 9: Average (Mean \pm SEM) of Correlation Coefficient in each condition between participants $(n=20)$. 


\section{Tables}

Table 1: First-person reports. Each participant $(n=23)$ provided a short personal report of the experience during the abstract thought (AT), rest, and visual-imagery conditions in each of the abstract-thought scans (the order of the scans is given in column 2).

* From the reports given by participants 7 and 23 in the abstract thought 1 scan, it could be understood that the contrast AT1 vs. rest could not be representative, due to conceptual mistakes (marked by one asterisk), thus these two participant were excluded from further analyses.

**This participant was excluded due to missing neural data.

\begin{tabular}{|c|c|c|c|c|c|c|c|}
\hline \multirow[b]{2}{*}{ 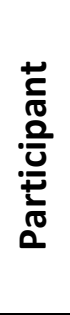 } & \multirow[b]{2}{*}{ 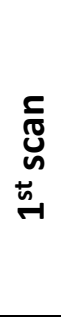 } & \multicolumn{3}{|c|}{ Abstract thought 1 scan } & \multicolumn{3}{|c|}{ Abstract thought 2 scan } \\
\hline & & 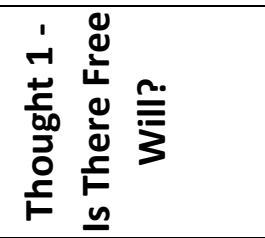 & $\begin{array}{l}\breve{y} \\
\check{\Perp}\end{array}$ & 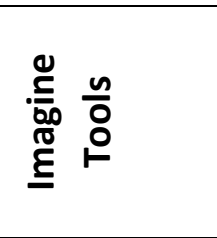 & 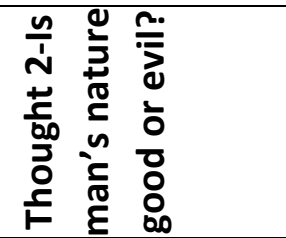 & $\begin{array}{l}\breve{y} \\
\ddot{x}\end{array}$ & 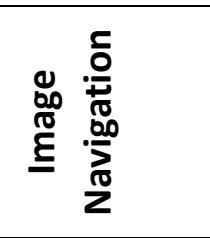 \\
\hline 1 & 1 & $\begin{array}{l}\text { I thought about } \\
\text { what is desire } \\
\text { and freedom, } \\
\text { afterwards I went } \\
\text { into it and I } \\
\text { thought about } \\
\text { whether it is } \\
\text { related to } \\
\text { control, and even } \\
\text { deeper into it. }\end{array}$ & $\begin{array}{l}\text { I tried to focus } \\
\text { visually on the } \\
\text { inside of the } \\
\text { eyelid in order } \\
\text { to not think too } \\
\text { much, I saw } \\
\text { darkness }\end{array}$ & $\begin{array}{l}\text { In a jewelry } \\
\text { making store, } \\
\text { I imagined I } \\
\text { was holding } \\
\text { them }\end{array}$ & $\begin{array}{l}\text { It started very } \\
\text { verbally, I analyzed } \\
\text { what is bad and } \\
\text { good and what is } \\
\text { human's nature, } \\
\text { then it became } \\
\text { more abstract, and } \\
\text { in the end I went } \\
\text { back to literal } \\
\text { meaning and } \\
\text { patterns, as I } \\
\text { learned to do in } \\
\text { sociology }\end{array}$ & $\begin{array}{l}\text { I did the same } \\
\text { thing as before, } \\
\text { but it was } \\
\text { harder to break } \\
\text { away from the } \\
\text { previous task }\end{array}$ & $\begin{array}{l}\text { From the } \\
\text { perspective } \\
\text { of levitation, I } \\
\text { imagined } \\
\text { familiar } \\
\text { routes }\end{array}$ \\
\hline 2 & 2 & $\begin{array}{l}\text { The Torah was } \\
\text { the starting point } \\
\text { and from there I } \\
\text { asked questions } \\
\text { about religion } \\
\text { and democracy }\end{array}$ & $\begin{array}{l}\text { I sang in my } \\
\text { heart with } \\
\text { thoughts in the } \\
\text { background }\end{array}$ & $\begin{array}{l}\text { I was in New } \\
\text { York, and } \\
\text { pictured } \\
\text { kitchenware, } \\
\text { and called } \\
\text { them by their } \\
\text { name }\end{array}$ & $\begin{array}{l}\text { I thought about } \\
\text { parashat (section } \\
\text { of the torah) "Ki } \\
\text { Tavo", blessings } \\
\text { and curses, I } \\
\text { thought about } \\
\text { Noah and } \\
\text { wondered why } \\
\text { should one be bad }\end{array}$ & $\begin{array}{l}\text { There was a } \\
\text { song in my } \\
\text { heart, I } \\
\text { attempted to } \\
\text { continue the } \\
\text { song from } \\
\text { where I left off } \\
\text { last time, with } \\
\text { thoughts }\end{array}$ & $\begin{array}{l}\text { I always } \\
\text { walked in the } \\
\text { same route in } \\
\text { New York }\end{array}$ \\
\hline
\end{tabular}




\begin{tabular}{|c|c|c|c|c|c|c|c|}
\hline & & & & & $\begin{array}{l}\text { or good, what is } \\
\text { the profit? }\end{array}$ & $\begin{array}{l}\text { running in the } \\
\text { background }\end{array}$ & \\
\hline 3 & 1 & $\begin{array}{l}\text { I tried, there was } \\
\text { not enough time. } \\
\text { I presented my } \\
\text { opinion and } \\
\text { arguments with } \\
\text { pros and cons. } \\
\text { There's this idea } \\
\text { that things you're } \\
\text { doing come back } \\
\text { to you, I was } \\
\text { thinking about } \\
\text { whether I had } \\
\text { free will during } \\
\text { this experiment, I } \\
\text { was leaning on } \\
\text { old thoughts in } \\
\text { this subject }\end{array}$ & $\begin{array}{l}\text { I easily } \\
\text { disconnected } \\
\text { from the task, } \\
\text { there was } \\
\text { nothing specific }\end{array}$ & $\begin{array}{l}\text { I imagined a } \\
\text { housewares } \\
\text { shop }\end{array}$ & $\begin{array}{l}\text { I thought about } \\
\text { whether the effect } \\
\text { was genetic or } \\
\text { environmental } \\
\text { (nature or } \\
\text { nurture), and was } \\
\text { it good or bad }\end{array}$ & $\begin{array}{l}\text { I caught myself } \\
\text { thinking about } \\
\text { my chores at } \\
\text { the start of my } \\
\text { resting phase }\end{array}$ & $\begin{array}{l}\text { Tracks that I } \\
\text { walked on } \\
\text { near my } \\
\text { house, } \\
\text { through the } \\
\text { eyes of the } \\
\text { walker }\end{array}$ \\
\hline 4 & 1 & $\begin{array}{l}\text { I do not believe } \\
\text { in free will } \\
\text { because the head } \\
\text { is activated by } \\
\text { chemistry, for a } \\
\text { very long time I } \\
\text { think this way }\end{array}$ & $\begin{array}{l}\text { I made an effort } \\
\text { to clear my } \\
\text { head from any } \\
\text { thoughts }\end{array}$ & $\begin{array}{l}\text { I imagined a } \\
\text { box of tools }\end{array}$ & $\begin{array}{l}\text { All human qualities } \\
\text { are dual, but each } \\
\text { quality is dominant } \\
\text { at a different } \\
\text { certain time }\end{array}$ & $\begin{array}{l}\text { I tried to erase } \\
\text { every thought }\end{array}$ & $\begin{array}{l}\text { Through } \\
\text { houses, from } \\
\text { my house to } \\
\text { work }\end{array}$ \\
\hline 5 & 1 & $\begin{array}{l}\text { I tried to build a } \\
\text { neurobiological } \\
\text { argument and to } \\
\text { test it }\end{array}$ & $\begin{array}{l}\text { I felt that the } \\
\text { rest } \\
\text { disconnected } \\
\text { me from being } \\
\text { awake and in } \\
\text { focus }\end{array}$ & $\begin{array}{l}\text { I went } \\
\text { through a } \\
\text { variety of } \\
\text { tools, I did } \\
\text { not succeed } \\
\text { in separating } \\
\text { the tool from } \\
\text { what it is } \\
\text { used for }\end{array}$ & $\begin{array}{l}\text { I tried to define it, } \\
\text { it was very visual, } \\
\text { every time I } \\
\text { attempted to } \\
\text { develop a } \\
\text { discussion, what } \\
\text { followed were } \\
\text { images }\end{array}$ & $\begin{array}{l}\text { While I rested } \\
\text { this time, it was } \\
\text { harder to let go } \\
\text { of the tasks, } \\
\text { especially after } \\
\text { the language } \\
\text { assignment }\end{array}$ & $\begin{array}{l}\text { I hovered in } \\
\text { the air over } \\
\text { familiar } \\
\text { routes, } \\
\text { everything } \\
\text { went by very } \\
\text { fast }\end{array}$ \\
\hline 6 & 2 & $\begin{array}{l}\text { It was a new } \\
\text { thought that I } \\
\text { had not } \\
\text { encountered } \\
\text { before, therefore } \\
\text { it was interesting }\end{array}$ & $\begin{array}{l}\text { I had awareness } \\
\text { of bodily } \\
\text { sensations, } \\
\text { both real and } \\
\text { those stemming } \\
\text { from internal } \\
\text { dialogue }\end{array}$ & $\begin{array}{l}\text { It was } \\
\text { difficult, I am } \\
\text { not familiar } \\
\text { with many } \\
\text { tools and I } \\
\text { started to fill } \\
\text { them with } \\
\text { content }\end{array}$ & $\begin{array}{l}\text { It translated into a } \\
\text { question: is there } \\
\text { meaning in the evil } \\
\text { projected towards } \\
\text { me or others, and } \\
\text { is there a choice, } \\
\text { do we serve } \\
\text { something positive } \\
\text { even when we do } \\
\text { something evil? }\end{array}$ & $\begin{array}{l}\text { I was calm, the } \\
\text { feeling was } \\
\text { positive and } \\
\text { quiet }\end{array}$ & $\begin{array}{l}\text { I imagined } \\
\text { that I was } \\
\text { running in a } \\
\text { route, like in } \\
\text { life }\end{array}$ \\
\hline
\end{tabular}




\begin{tabular}{|c|c|c|c|c|c|c|c|}
\hline 7* & 1 & $\begin{array}{l}\text { I forgot the } \\
\text { precise } \\
\text { instructions and } \\
\text { thought of } \\
\text { abstract contents } \\
\text { related to work* }\end{array}$ & $\begin{array}{l}\text { The body was } \\
\text { very relaxed, I } \\
\text { did not have } \\
\text { many thoughts, } \\
\text { rather, I } \\
\text { concentrated } \\
\text { on my physical } \\
\text { sensations }\end{array}$ & $\begin{array}{l}\text { There was a } \\
\text { familiar } \\
\text { kitchenware } \\
\text { tool in the } \\
\text { shop, I saw } \\
\text { the details }\end{array}$ & $\begin{array}{l}\text { In the beginning I } \\
\text { was speaking to } \\
\text { myself, and then } \\
\text { having a } \\
\text { conversation with } \\
\text { someone else, like } \\
\text { a dialogue }\end{array}$ & $\begin{array}{l}\text { Like before, but } \\
\text { it was harder to } \\
\text { calm down and } \\
\text { return to rest }\end{array}$ & $\begin{array}{l}\text { I walked in } \\
\text { familiar and } \\
\text { new routes }\end{array}$ \\
\hline 8 & 1 & $\begin{array}{l}\text { I tried to examine } \\
\text { the meaning of } \\
\text { free will, and the } \\
\text { fact that a person } \\
\text { lives in a society }\end{array}$ & $\begin{array}{l}\text { Not a lot } \\
\text { happened, } \\
\text { there was } \\
\text { awareness } \\
\text { without having } \\
\text { to continue the } \\
\text { previous } \\
\text { condition- that } \\
\text { in itself was a } \\
\text { thought, I just } \\
\text { listened to the } \\
\text { magnet and } \\
\text { breath }\end{array}$ & $\begin{array}{l}\text { It was } \\
\text { difficult to } \\
\text { see tools in a } \\
\text { static form }\end{array}$ & $\begin{array}{l}\text { I broke the } \\
\text { sentence into } \\
\text { factors, what is the } \\
\text { absolute good and } \\
\text { evil? What is } \\
\text { human nature - a } \\
\text { common thing? } \\
\text { Afterward, I asked } \\
\text { what was the basis } \\
\text { for this - at what } \\
\text { stage do we } \\
\text { examine this? } \\
\text { Before birth? }\end{array}$ & $\begin{array}{l}\text { Quite similar to } \\
\text { the former. In } \\
\text { the transition } \\
\text { to resting phase } \\
\text { there is an } \\
\text { image of closing } \\
\text { a book, } \\
\text { connected to } \\
\text { closing the } \\
\text { previous task }\end{array}$ & $\begin{array}{l}\text { From home } \\
\text { to work and } \\
\text { reference } \\
\text { points on the } \\
\text { way, I walked } \\
\text { every time } \\
\text { from the } \\
\text { point I } \\
\text { stopped }\end{array}$ \\
\hline 9 & 2 & $\begin{array}{l}\text { It was a complex } \\
\text { process for all } \\
\text { kinds of reasons, } \\
\text { I thought of } \\
\text { experiments that } \\
\text { involved lifting a } \\
\text { hand and } \\
\text { decisions and so } \\
\text { forth }\end{array}$ & $\begin{array}{l}\text { I had a more } \\
\text { difficult time } \\
\text { disconnecting } \\
\text { from this } \\
\text { session in } \\
\text { comparison to } \\
\text { the previous } \\
\text { task }\end{array}$ & $\begin{array}{l}\text { I visited four } \\
\text { different } \\
\text { stores }\end{array}$ & $\begin{array}{l}\text { I thought about } \\
\text { what it means } \\
\text { when we do bad } \\
\text { things? It does not } \\
\text { indicate evil, there } \\
\text { is a natural } \\
\text { inclination and } \\
\text { there is a choice. I } \\
\text { had a prior } \\
\text { opinion, therefore, } \\
\text { it was not } \\
\text { challenging }\end{array}$ & $\begin{array}{l}\text { I succeeded in } \\
\text { letting go of the } \\
\text { previous task }\end{array}$ & $\begin{array}{l}\text { (missing } \\
\text { data) }\end{array}$ \\
\hline 10 & 1 & $\begin{array}{l}\text { I thought about } \\
\text { how in the } \\
\text { experiment I was } \\
\text { beginning and } \\
\text { stopping the } \\
\text { thinking, and } \\
\text { whether I could } \\
\text { ever stop } \\
\text { thinking }\end{array}$ & $\begin{array}{l}\text { I thought about } \\
\text { how it is } \\
\text { impossible to } \\
\text { stop thinking at } \\
\text { once, I was } \\
\text { wondering } \\
\text { what my pupils } \\
\text { were doing, and } \\
\text { whether it } \\
\text { changes from } \\
\text { condition to } \\
\text { condition }\end{array}$ & $\begin{array}{l}\text { I imagined a } \\
\text { warehouse } \\
\text { for kayaks, } \\
\text { their shape } \\
\text { and how I } \\
\text { held my hand }\end{array}$ & $\begin{array}{l}\text { I thought about } \\
\text { what defines good } \\
\text { and evil, is it } \\
\text { relative or } \\
\text { absolute? How is it } \\
\text { defined in different } \\
\text { religions? Does a } \\
\text { good person define } \\
\text { the good in the } \\
\text { same way as a bad } \\
\text { person? Does the } \\
\text { definition changed } \\
\text { depending on the } \\
\text { definer? }\end{array}$ & $\begin{array}{l}\text { I retracted to } \\
\text { thinking about } \\
\text { algorithms from } \\
\text { work, I felt a } \\
\text { physical } \\
\text { discomfort } \\
\text { from lying } \\
\text { down for a } \\
\text { while }\end{array}$ & $\begin{array}{l}\text { I walked in } \\
\text { the jungle } \\
\text { and saw } \\
\text { monkeys in } \\
\text { the trees, I } \\
\text { rowed in the } \\
\text { ocean and } \\
\text { saw the } \\
\text { shoreline }\end{array}$ \\
\hline
\end{tabular}




\begin{tabular}{|c|c|c|c|c|c|c|c|}
\hline 11 & 2 & $\begin{array}{l}\text { I thought that } \\
\text { desire has a } \\
\text { temporal aspect, } \\
\text { whether it exists } \\
\text { all the time and } \\
\text { whether it has } \\
\text { meaning when it } \\
\text { is not } \\
\text { remembered }\end{array}$ & $\begin{array}{l}\text { The assignment } \\
\text { kind of slid } \\
\text { inside, into my } \\
\text { chest }\end{array}$ & $\begin{array}{l}\text { Tools are for } \\
\text { motion - it } \\
\text { was hard to } \\
\text { see them } \\
\text { static }\end{array}$ & $\begin{array}{l}\text { I thought about } \\
\text { good and evil, } \\
\text { what it is for me } \\
\text { and another; } \\
\text { however, I did not } \\
\text { get to the question } \\
\text { of the nature of } \\
\text { man }\end{array}$ & $\begin{array}{l}\text { The experience } \\
\text { was quite } \\
\text { physical, part of } \\
\text { the time things } \\
\text { from the } \\
\text { previous blocks } \\
\text { returned }\end{array}$ & $\begin{array}{l}\text { I walked } \\
\text { home from } \\
\text { work; } \\
\text { however, I } \\
\text { did not feel } \\
\text { my body }\end{array}$ \\
\hline 12 & 1 & $\begin{array}{l}\text { At first it was } \\
\text { hard to enter the } \\
\text { thought because } \\
\text { I skipped } \\
\text { between topics, } \\
\text { in the end it } \\
\text { became simple }\end{array}$ & $\begin{array}{l}\text { I tried to follow } \\
\text { a method, I } \\
\text { always thought } \\
\text { about releasing } \\
\text { tension from } \\
\text { the body }\end{array}$ & $\begin{array}{l}\text { Every time I } \\
\text { took a tool } \\
\text { and thought } \\
\text { about how it } \\
\text { worked and } \\
\text { why I lacked } \\
\text { it in my work }\end{array}$ & $\begin{array}{l}\text { I tried to build a } \\
\text { dialogue arguing } \\
\text { for and against, I } \\
\text { experienced a little } \\
\text { excitement from } \\
\text { the verbal duel }\end{array}$ & $\begin{array}{l}\text { There was a } \\
\text { little inertia, it } \\
\text { was hard for } \\
\text { me to break } \\
\text { away from the } \\
\text { previous task }\end{array}$ & $\begin{array}{l}\text { I walked to } \\
\text { the preschool } \\
\text { from home }\end{array}$ \\
\hline 13 & 2 & $\begin{array}{l}\text { I managed to } \\
\text { have new } \\
\text { thoughts, and } \\
\text { not think of past } \\
\text { thoughts in the } \\
\text { field }\end{array}$ & $\begin{array}{l}\text { After the } \\
\text { language } \\
\text { assignment it } \\
\text { was harder to } \\
\text { break away, I } \\
\text { was focused on } \\
\text { whether I } \\
\text { succeeded }\end{array}$ & $\begin{array}{l}\text { For the most } \\
\text { part work } \\
\text { tools and } \\
\text { houseware } \\
\text { tools }\end{array}$ & $\begin{array}{l}\text { I tried to think of a } \\
\text { new thought; } \\
\text { however, I was } \\
\text { having a hard time } \\
\text { disconnecting from } \\
\text { my previous } \\
\text { thoughts because I } \\
\text { am a criminal } \\
\text { attorney }\end{array}$ & $\begin{array}{l}\text { The resting } \\
\text { phase really } \\
\text { helped clear my } \\
\text { head }\end{array}$ & $\begin{array}{l}\text { Sometimes I } \\
\text { walked, } \\
\text { sometimes I } \\
\text { drove }\end{array}$ \\
\hline 14 & 1 & $\begin{array}{l}\text { For the possible } \\
\text { freedom, I } \\
\text { thought about } \\
\text { situations in } \\
\text { which I would do } \\
\text { anything to be } \\
\text { free }\end{array}$ & $\begin{array}{l}\text { I imagined } \\
\text { turning over on } \\
\text { my side and } \\
\text { falling asleep - } \\
\text { every time it } \\
\text { took a while to } \\
\text { get there, } \\
\text { because I was } \\
\text { preoccupied } \\
\text { with a sense of } \\
\text { defeat or } \\
\text { success from } \\
\text { the previous } \\
\text { task }\end{array}$ & $\begin{array}{l}\text { Every time I } \\
\text { was with } \\
\text { different } \\
\text { agricultural } \\
\text { tools }\end{array}$ & $\begin{array}{l}\text { This time was } \\
\text { more interesting. I } \\
\text { thought that we } \\
\text { are born virgins } \\
\text { and only } \\
\text { afterwards adapt }\end{array}$ & $\begin{array}{l}\text { It's hard for me } \\
\text { to rest when I } \\
\text { wait for the } \\
\text { next } \\
\text { assignment }\end{array}$ & $\begin{array}{l}\text { A bike trail } \\
\text { and driving in } \\
\text { a car }\end{array}$ \\
\hline $15^{* *}$ & 1 & $\begin{array}{l}\text { I thought there } \\
\text { was free will, I } \\
\text { repeated the } \\
\text { argument in } \\
\text { favor of free will }\end{array}$ & $\begin{array}{l}\text { I had a difficult } \\
\text { time with } \\
\text { resting after } \\
\text { the assignment, } \\
\text { it took me a } \\
\text { few seconds }\end{array}$ & $\begin{array}{l}\text { Kitchenware } \\
\text { in various } \\
\text { combinations }\end{array}$ & $\begin{array}{l}\text { I raised arguments } \\
\text { both for and } \\
\text { against, there was } \\
\text { an active } \\
\text { discussion }\end{array}$ & $\begin{array}{l}\text { It was easier for } \\
\text { me to return to } \\
\text { resting in } \\
\text { comparison to } \\
\text { the previous } \\
\text { time }\end{array}$ & $\begin{array}{l}\text { Part of it was } \\
\text { in the car or } \\
\text { when } \\
\text { walking, part } \\
\text { of it while } \\
\text { hovering }\end{array}$ \\
\hline
\end{tabular}




\begin{tabular}{|c|c|c|c|c|c|c|c|}
\hline 16 & 1 & $\begin{array}{l}\text { I discussed the } \\
\text { issue of whether } \\
\text { the will is truly } \\
\text { free or dictated } \\
\text { by society and } \\
\text { expectations, it } \\
\text { was like an } \\
\text { internal } \\
\text { discussion }\end{array}$ & $\begin{array}{l}\text { I tried to calm } \\
\text { down my mind, } \\
\text { like a vacuum, } \\
\text { not to think } \\
\text { about anything. } \\
\text { I think I } \\
\text { succeeded, } \\
\text { without } \\
\text { thoughts and } \\
\text { feelings }\end{array}$ & $\begin{array}{l}\text { I'm good at it } \\
\text { and know the } \\
\text { tools }\end{array}$ & $\begin{array}{l}\text { I thought about } \\
\text { whether man is } \\
\text { born neutral, and } \\
\text { that traits are } \\
\text { acquired during } \\
\text { socializing. In } \\
\text { general, man is } \\
\text { supposed to be } \\
\text { good from his } \\
\text { youth. That's the } \\
\text { way I depict the } \\
\text { Nazi's in my head }\end{array}$ & $\begin{array}{l}\text { I tried to be } \\
\text { consistent and } \\
\text { to stop the } \\
\text { processes } \\
\text { during rest, } \\
\text { completely, do } \\
\text { be completely } \\
\text { detached, like a } \\
\text { complete } \\
\text { shutdown }\end{array}$ & $\begin{array}{l}\text { I saw routes } \\
\text { in great } \\
\text { detail, like in } \\
\text { google maps }\end{array}$ \\
\hline 17 & 2 & $\begin{array}{l}\text { I tried to think } \\
\text { about free will, I } \\
\text { feel that I } \\
\text { succeeded in it }\end{array}$ & $\begin{array}{l}\text { There were } \\
\text { fewer changes } \\
\text { in the sense of } \\
\text { time and less } \\
\text { leakage of } \\
\text { blocks into the } \\
\text { two }\end{array}$ & $\begin{array}{l}\text { Musical } \\
\text { instruments } \\
\text { and drills }\end{array}$ & $\begin{array}{l}\text { I moved between } \\
\text { Hebrew and } \\
\text { English, it was } \\
\text { hard, but I } \\
\text { managed to think } \\
\text { about related } \\
\text { things, it was } \\
\text { associative }\end{array}$ & $\begin{array}{l}\text { It felt as if the } \\
\text { resting time } \\
\text { was much } \\
\text { longer than the } \\
\text { assignment, } \\
\text { there was a } \\
\text { change in the } \\
\text { sense of time }\end{array}$ & $\begin{array}{l}\text { I hovered } \\
\text { over the } \\
\text { passing } \\
\text { landscape }\end{array}$ \\
\hline 18 & 1 & $\begin{array}{l}\text { I thought that } \\
\text { education affects } \\
\text { the will, and the } \\
\text { past limits free } \\
\text { thinking. I have } \\
\text { come to the } \\
\text { conclusion that } \\
\text { history seems to } \\
\text { limit ability, we } \\
\text { only want what } \\
\text { we imagine }\end{array}$ & $\begin{array}{l}\text { It was cold, I } \\
\text { sank into the } \\
\text { tone, it was like } \\
\text { anesthesia. I } \\
\text { felt calm. There } \\
\text { were many } \\
\text { thoughts }\end{array}$ & $\begin{array}{l}\text { A tool that I } \\
\text { need as a } \\
\text { draftsman }\end{array}$ & $\begin{array}{l}\text { I thought about } \\
\text { people I am } \\
\text { familiar with at } \\
\text { first, then I } \\
\text { analyzed the } \\
\text { definitions of good } \\
\text { and evil, and } \\
\text { thought about our } \\
\text { nature to do } \\
\text { anything for } \\
\text { survival }\end{array}$ & $\begin{array}{l}\text { At first, the } \\
\text { transition from } \\
\text { the thought to } \\
\text { resting was } \\
\text { difficult, but } \\
\text { with an } \\
\text { ambitious } \\
\text { attempt, I did } \\
\text { succeed in } \\
\text { disconnecting }\end{array}$ & $\begin{array}{l}\text { In the } \\
\text { beginning } \\
\text { while sitting } \\
\text { in the car, } \\
\text { afterwards it } \\
\text { was like one } \\
\text { was } \\
\text { navigating } \\
\text { with a map }\end{array}$ \\
\hline 19 & 1 & $\begin{array}{l}\text { I imagined } \\
\text { people arguing, } \\
\text { and I brought } \\
\text { contradicting } \\
\text { thoughts }\end{array}$ & $\begin{array}{l}\text { I imagined a } \\
\text { computer } \\
\text { screen, } \\
\text { throwing } \\
\text { something into } \\
\text { the recycling } \\
\text { bin, so I threw } \\
\text { the thought } \\
\text { away, and } \\
\text { other thoughts } \\
\text { entered }\end{array}$ & $\begin{array}{l}\text { I thought of } \\
\text { game pieces } \\
\text { and } \\
\text { bathroom } \\
\text { accessories }\end{array}$ & $\begin{array}{l}\text { It was like an } \\
\text { argument, a } \\
\text { debate between } \\
\text { two } \\
\text { representatives, } \\
\text { claiming opposite } \\
\text { arguments }\end{array}$ & $\begin{array}{l}\text { It cut me off } \\
\text { from the } \\
\text { previous } \\
\text { assignment, } \\
\text { and then } \\
\text { different } \\
\text { thoughts } \\
\text { entered my } \\
\text { mind }\end{array}$ & $\begin{array}{l}\text { I rode a train } \\
\text { through } \\
\text { familiar } \\
\text { routes in } \\
\text { between } \\
\text { houses }\end{array}$ \\
\hline 20 & 2 & $\begin{array}{l}\text { I made } \\
\text { arguments for } \\
\text { and against, I } \\
\text { thought it could } \\
\text { be tested in the } \\
\text { MRI }\end{array}$ & $\begin{array}{l}\text { It was hard to } \\
\text { get rid of the } \\
\text { letter } \\
\text { combinations } \\
\text { that preceded } \\
\text { the rest }\end{array}$ & $\begin{array}{l}\text { In the } \\
\text { beginning it } \\
\text { was great, } \\
\text { and them I } \\
\text { finished all }\end{array}$ & $\begin{array}{l}\text { I thought about } \\
\text { whether children } \\
\text { are good, how we } \\
\text { define good and } \\
\text { evil, individual in }\end{array}$ & $\begin{array}{l}\text { I successfully } \\
\text { disengaged } \\
\text { from the } \\
\text { previous task }\end{array}$ & $\begin{array}{l}\text { It was not } \\
\text { interesting, } \\
\text { but it went } \\
\text { well seeing } \\
\text { routes }\end{array}$ \\
\hline
\end{tabular}


bioRxiv preprint doi: https://doi.org/10.1101/546085; this version posted February 10, 2019. The copyright holder for this preprint (which was not certified by peer review) is the author/funder, who has granted bioRxiv a license to display the preprint in perpetuity. It is made available under aCC-BY-NC-ND 4.0 International license.

\begin{tabular}{|c|c|c|c|c|c|c|c|}
\hline & & & & $\begin{array}{l}\text { the working } \\
\text { tools }\end{array}$ & $\begin{array}{l}\text { reference to the } \\
\text { general public }\end{array}$ & & \\
\hline 21 & 1 & $\begin{array}{l}\text { I thought about } \\
\text { what limits our } \\
\text { thoughts, what } \\
\text { stops us, } \\
\text { education? }\end{array}$ & $\begin{array}{l}\text { I treated it as a } \\
\text { task, to } \\
\text { disengage from } \\
\text { the previous } \\
\text { task }\end{array}$ & $\begin{array}{l}\text { I went to } \\
\text { Holmes } \\
\text { Center, I saw } \\
\text { tools and } \\
\text { focused each } \\
\text { time on } \\
\text { something } \\
\text { different }\end{array}$ & $\begin{array}{l}\text { I did not } \\
\text { remember the } \\
\text { question, so I } \\
\text { thought about } \\
\text { what is a thought, } \\
\text { is it spirit or matter }\end{array}$ & $\begin{array}{l}\text { I felt a little } \\
\text { sleepy during } \\
\text { the session, and } \\
\text { it was difficult } \\
\text { for me to exit } \\
\text { my rest for the } \\
\text { assignment }\end{array}$ & $\begin{array}{l}\text { I drove in a } \\
\text { car between } \\
\text { houses }\end{array}$ \\
\hline 22 & 1 & $\begin{array}{l}\text { I thought about } \\
\text { free will, and I } \\
\text { continued to } \\
\text { focus on my } \\
\text { previous } \\
\text { thoughts }\end{array}$ & $\begin{array}{l}\text { While resting I } \\
\text { really did not } \\
\text { have any } \\
\text { thoughts, I was } \\
\text { trying hard for } \\
\text { the assignment }\end{array}$ & $\begin{array}{l}\text { Interesting } \\
\text { kitchenware }\end{array}$ & $\begin{array}{l}\text { I had a clear } \\
\text { opinion, but } \\
\text { nevertheless I tried } \\
\text { to develop a } \\
\text { discussion - but } \\
\text { everything went to } \\
\text { one side }\end{array}$ & $\begin{array}{l}\text { I tried to } \\
\text { automatically } \\
\text { analyze what } \\
\text { was in the } \\
\text { previous stages, } \\
\text { and I prepared } \\
\text { myself to } \\
\text { answer } \\
\text { questions }\end{array}$ & $\begin{array}{l}\text { I drove in a } \\
\text { car from my } \\
\text { home to } \\
\text { work }\end{array}$ \\
\hline $23 *$ & 2 & $\begin{array}{l}\text { The topic was } \\
\text { less interesting }\end{array}$ & $\begin{array}{l}\text { I thought that } \\
\text { the resting } \\
\text { phase is } \\
\text { associated with } \\
\text { the thought, } \\
\text { and I continued } \\
\text { to think about } \\
\text { the nature of } \\
\text { man * }\end{array}$ & $\begin{array}{l}\text { I imagined an } \\
\text { instrument } \\
\text { and a work } \\
\text { tool }\end{array}$ & It was interesting & $\begin{array}{l}\text { I saw the sky } \\
\text { and the ocean } \\
\text { and I rested }\end{array}$ & $\begin{array}{l}\text { I drove in the } \\
\text { car and once } \\
\text { walked }\end{array}$ \\
\hline
\end{tabular}


Table 2: Details of scans and tasks used in this study.

\begin{tabular}{|c|c|c|c|c|c|}
\hline Scan & Condition & Task & Length & Instruction & Cue \\
\hline \multirow{5}{*}{ 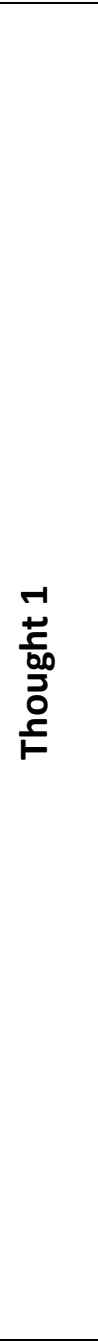 } & $\begin{array}{l}\text { Abstract } \\
\text { thought }\end{array}$ & $\begin{array}{l}\text { Abstract } \\
\text { thought } 1 \\
\text { (AT1) }\end{array}$ & $\begin{array}{l}5 \text { blocks (each } \\
21 \text { sec) } \\
\text { separated by } \\
\text { rest blocks }\end{array}$ & $\begin{array}{l}\text { Think about the question } \\
\text { "Is there free will?" }\end{array}$ & $\begin{array}{l}\text { Cue: "thought", cue } \\
\text { duration: } 850 \mathrm{~ms}\end{array}$ \\
\hline & $\begin{array}{l}\text { Visual } \\
\text { imagery }\end{array}$ & $\begin{array}{l}\text { Imagine } \\
\text { tools }\end{array}$ & $\begin{array}{l}5 \text { blocks (each } \\
21 \mathrm{sec}) \\
\text { separated by } \\
\text { rest blocks }\end{array}$ & $\begin{array}{l}\text { Visualize tools of your } \\
\text { preference (e.g. } \\
\text { working tools or } \\
\text { kitchenware) as you } \\
\text { imaginatively walk } \\
\text { through a big store and } \\
\text { screen the shelves }\end{array}$ & $\begin{array}{l}\text { Cue words: "imagine } \\
\text { tools", cue duration: } 1250 \\
\text { ms }\end{array}$ \\
\hline & \multirow[t]{2}{*}{ Language } & $\begin{array}{l}\text { Sentences } \\
\text { Conjugation }\end{array}$ & $\begin{array}{l}5 \text { blocks (each } \\
21 \mathrm{sec}) \\
\text { separated by } \\
\text { rest blocks }\end{array}$ & $\begin{array}{l}\text { Participants were given } \\
\text { sentences, and } \\
\text { instructed to conjugate } \\
\text { them to different } \\
\text { tenses/ objects. }\end{array}$ & $\begin{array}{l}\text { "He went to the sea"; } \\
\text { "She is buying bread"; } \\
\text { "You are going up"; "I will } \\
\text { sit in the garden"; "They } \\
\text { wore a coat" (respectively: } \\
1550,1550,1200,1800 \text {, } \\
1500 \mathrm{~ms} \text { ) }\end{array}$ \\
\hline & & $\begin{array}{l}\text { Letters } \\
\text { Working } \\
\text { Memory }\end{array}$ & $\begin{array}{l}5 \text { blocks (each } \\
21 \mathrm{sec}) \\
\text { separated by } \\
\text { rest blocks }\end{array}$ & $\begin{array}{l}\text { Press " } 1 \text { " if the last } \\
\text { letter was one of the six } \\
\text { letters, and " } 2 \text { " if not }\end{array}$ & $\begin{array}{l}1^{\text {st }} \text { cue: each time a } \\
\text { different series of six } \\
\text { Hebrew letters (e.g. "pe, } \\
\text { reish, kuf, gimel, lamed" } \\
\text { (cue durations } 2700-3200 \\
\text { ms) } \\
2^{\text {nd }} \text { cue: one Hebrew letter }\end{array}$ \\
\hline & \multicolumn{2}{|l|}{ Rest } & Each $12 \mathrm{sec}$ & Rest as best as you can & $\begin{array}{l}\text { Cue: "rest", cue duration: } \\
620 \mathrm{~ms}\end{array}$ \\
\hline \multirow{4}{*}{ 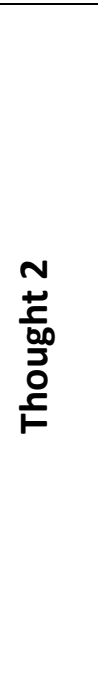 } & $\begin{array}{l}\text { Abstract } \\
\text { thought }\end{array}$ & $\begin{array}{l}\text { Abstract } \\
\text { thought } 2 \\
\text { (AT2) }\end{array}$ & $\begin{array}{l}5 \text { blocks (each } \\
21 \text { sec) } \\
\text { separated by } \\
\text { rest blocks }\end{array}$ & $\begin{array}{l}\text { Think about the } \\
\text { question "Is man's } \\
\text { nature good or evil?" }\end{array}$ & $\begin{array}{l}\text { Cue word: "thought", cue } \\
\text { duration: } 850 \mathrm{~ms}\end{array}$ \\
\hline & $\begin{array}{l}\text { Visual } \\
\text { imagery }\end{array}$ & $\begin{array}{l}\text { Imagine } \\
\text { navigation }\end{array}$ & $\begin{array}{l}5 \text { blocks (each } \\
21 \text { sec) } \\
\text { separated by } \\
\text { rest blocks }\end{array}$ & $\begin{array}{l}\text { Visualize a navigation of } \\
\text { your route home }\end{array}$ & $\begin{array}{l}\text { Cue words: "imagine } \\
\text { navigation", cue duration: } \\
1350 \text { ms }\end{array}$ \\
\hline & Language & $\begin{array}{l}\text { Verbal } \\
\text { fluency }\end{array}$ & $\begin{array}{l}5 \text { blocks (each } \\
21 \mathrm{sec}) \\
\text { separated by } \\
\text { rest blocks }\end{array}$ & $\begin{array}{l}\text { Generate continuously } \\
\text { and silently new words } \\
\text { which start with the cue } \\
\text { letter }\end{array}$ & $\begin{array}{l}\text { Cue letters were: } \\
\text { "a/b/g/r/n", cue duration: } \\
500,350,650,500 \text {, and } \\
730 \text { ms respectively }\end{array}$ \\
\hline & \multicolumn{2}{|l|}{ Rest } & Each $12 \mathrm{sec}$ & Rest as best as you can & $\begin{array}{l}\text { cue: "rest", cue duration: } \\
620 \mathrm{~ms}\end{array}$ \\
\hline
\end{tabular}


bioRxiv preprint doi: https://doi.org/10.1101/546085; this version posted February 10, 2019. The copyright holder for this preprint (which was not certified by peer review) is the author/funder, who has granted bioRxiv a license to display the preprint in perpetuity. It is made available under aCC-BY-NC-ND 4.0 International license.

\begin{tabular}{|c|c|c|c|c|c|}
\hline \multirow{5}{*}{ 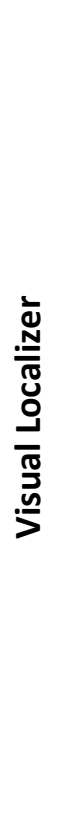 } & \multirow[t]{4}{*}{ Visual } & Faces & \multirow[b]{4}{*}{$\begin{array}{l}\text { Each } \\
\text { condition had } \\
7 \text { blocks } \\
\text { (pseudo- } \\
\text { random } \\
\text { order), each } \\
\text { lasted } 9 \text { sec, } \\
\text { (followed by } \\
\text { rest) - } 9 \\
\text { images in } \\
\text { each block; } \\
\text { (each for } 800 \\
\text { ms followed } \\
\text { by a } 200 \text { ms } \\
\text { blank screen) }\end{array}$} & \multirow{4}{*}{$\begin{array}{l}\text { Fixate on the central } \\
\text { fixation dot, and report } \\
\text { whether the presented } \\
\text { stimulus was identical } \\
\text { to the previous stimulus } \\
\text { or not, by pressing the } \\
\text { buttons " } 2 \text { " or " } 1 \text { ", } \\
\text { respectively }\end{array}$} & \multirow{4}{*}{$\begin{array}{l}\text { Stationary gray scale line } \\
\text { drawings of faces, } \\
\text { buildings, common man- } \\
\text { made objects, and } \\
\text { geometric patterns ( } 16 \text { of } \\
\text { each type). A central red } \\
\text { fixation point was present } \\
\text { throughout the } \\
\text { experiment, including the } \\
\text { fixation blocks }\end{array}$} \\
\hline & & Houses & & & \\
\hline & & Objects & & & \\
\hline & & Patterns & & & \\
\hline & Rest & & $\begin{array}{l}6 \text { sec blank } \\
\text { screen }\end{array}$ & $\begin{array}{l}\text { Fixate on the central } \\
\text { fixation dot }\end{array}$ & $\begin{array}{l}\text { A central red fixation } \\
\text { point }\end{array}$ \\
\hline
\end{tabular}

